\title{
Katılım Bankalarının Finansal Performanslarının TOPSIS Yöntemi İle Uluslararası Boyutta Değerlendirilmesi ${ }^{1}$
}

\author{
Bekir Elmas*
}

Aslihan Yetim**

Received: 03.06 .2021

Accepted: 27.10.2021

DOI: $10.25272 /$ ijisef.941972

Type: Research Article

\section{Öz}

Bu çalışma katılım bankalarının finansal performanslarını uluslararası boyutta karşılaştırmalı olarak incelemektedir. IFDI 2012-2019 raporunun küresel İslami bankacilık toplam aktifleri siralamasında ilk $10^{\prime}$ da yer alan ülkelerden verilerine düzenli olarak ulaşılabilen ve raporlama tarihleri Türkiye ile benzerlik gösteren ülkelerin (Suudi Arabistan, Malezya, BAE, Kuveyt, Türkiye ve Bahreyn) 2012-2019 dönemine ait verileri TOPSIS yöntemi ile analiz edilerek finansal performans sıralaması oluşturulmuştur. Çalışmada kullanılan finansal oranlar; sermaye, yeterlilik, bilanço yapısı, aktif kalitesi, likidite ve kârlılık oranları olup kullanılan yöntem ise çok kriterli karar verme yöntemlerinden TOPSIS yöntemidir. Çalışmanın temel amacı bu ülkelerin küresel İslami bankacılık toplam aktif payları ile finansal performans sıralamalarını karşılaştırmaktır. Ayrıca Türkiye'nin küresel katılım bankacılığı sektöründeki finansal performans siralamasına göre mevcut durumunu tespit etmek hedeflenmektedir. Çalışmanın sonucunda ülkelerin genel performans sıralamaları ile küresel İslami bankacılık toplam aktif payları sıralamasının birebir aynı olduğu tespit edilmiştir. Türkiye ise her iki sıralamada da 5 . sırada yer almıştır.

Anahtar Kelimeler: Katılım Bankacılığı, İslami Bankacılık, TOPSIS, Finansal Performans

Jel Kodlar1: G21

\section{Evaluation of Financial Performances of Participation Banks with The TOPSIS Method in International Dimensions}

\begin{abstract}
This study examines the financial performances of participation banks on an international scale comparatively. 2012-2019 datas of the countries which are in the first ten placement of IFDI 2012-2019 report of International Islamic Banking total assets and whose datas are accessible and show similarity to Turkey (Saudi Arabia, Malaysia, United Arab Emirates, Kuwait, Turkey and Bahrain) were analyzed by TOPSIS method and financial performances were sorted. Financial ratios used in the study; capital adequacy, balance sheet structure, asset quality, liquidity and profitability ratios and the method used is TOPSIS method, which is one of the multi-criteria decision making methods. The main purpose of the study is to compare the Global Islamic Banking Total Asset shares of these countries with their

\footnotetext{
${ }^{1}$ Bu çalışma aynı isimli yüksek lisans tezinden türetilmiştir.

** Arş. Gör., Atatürk Üniversitesi İ.̇̇.B.F., aslihan.yetim@atauni.edu.tr, ORCID: 0000-0003-0996-0035
}

* Prof. Dr., Atatürk Üniversitesi İ.İ.B.F., belmas@atauni.edu.tr, ORCID: 0000-0002-2094-2180
\end{abstract}


financial performance rankings. In addition, it is aimed to determine the current situation of Turkey according to the financial performance ranking in the global participation banking sector. As a result of the study, it has been determined that the general performance rankings of the countries and the global Islamic banking total asset share ranking are exactly the same. Turkey, on the other hand, took the 5th place in both rankings.

Keywords: Participation Banking, Islamic Banking, TOPSIS, Financial Performance

Jel Codes: G21

\section{Giriş}

Dünya literatüründe faizsiz bankacılık faaliyetlerini yürüten kurumların oluşturduğu bankacılık sistemi, İslami bankacilık sistemi olarak kabul edilmektedir. Ülkemizde ise bu kurumların oluşturduğu bankacılık sistemi, Katılım Bankacılığı olarak adlandırılmaktadır.

İslami ekonomi, İslamiyet'in ortaya çıktığı dönemlere kadar dayanmaktadır. İslami finansın günümüzdeki çerçeveye ulaşması 1960'l1 yıllardan itibaren söz konusu olmuştur. 1962'de Malezya' da Hac Fon Girişimi kurulmuştur (Erdem ve Tatll, 2020: 43). 1963 yılında Misır'da Mit-Ghamr bölgesinde köy sandığına benzeyen bir İslami tasarruf bankası kurulmuştur. Modern anlamda ilk faizsiz bankacılık örneği sayılabilecek olan ve Almanya'dan destek alan bu Tasarruf Bankası, kasaba halkının tarımsal ve ticari faaliyetlerini desteklemiştir. Ayrıca tekâfül, mudarebe, icâre ve takas gibi İslami finans araçlarını kullanmıştır (Canbaz, 2018: 196). 1970'li yıllarda petrolde yaşanan gelişmeler Arap ülkelerinin tasarruflarının artmasına neden olmuş ve bu tasarrufların yatırım amacıyla değerlendirilmesi ihtiyacını ortaya çıarmıştır. Gelişmelerin devamında 1971 yılında Mısır'da ilk faizsiz ticari banka olan Nasr Sosyal Bankası kurulmuştur (SERPAM, 2013: 9). Ardından 1976 ve 1977 yıllarında İslami Ekonomi Konferansları düzenlenmiştir. Bu gelişmelerin sonucunda İslam Kalkınma Bankası kurulmuştur. Dünyada faizsiz bankacılık alanında ilk kurulan özel banka 1975 yılında Dubai İslam Bankası olmuştur. 1990'lara kadar faizsiz bankacılık yavaş seyirde gelişme göstererek Ortadoğu ülkeleri ve Malezya ile sınırlı kalmıştır. Günümüzde ise oldukça geniş bir pazar payına sahiptir. (Alrifai, 2017: 154-155). 2005 yılına gelindiğinde faizsiz bankacılık sektörünün gelişimini sağlamak amacıyla kredi ve risk unsurlarını belirleyen İslami Uluslararası Derecelendirme Kuruluşu (IIRA) oluşturulmuştur. (Çelik ve Doğan, 2017: 27).

İslami bankacılık sektöründe dünyada önde gelen ülkeler İran, Suudi Arabistan, BAE (Birleşik Arap Emirlikleri), Kuveyt, Katar, Malezya gibi ülkelerdir. İslami bankacılık toplam aktifleri sıralamasında Endonezya, Bahreyn, Türkiye ve Bangladeş gibi ülkeler de ilk on sırada bulunmaktadır. Bangladeş ve Malezya gibi ülkeler dual bankacılık yapısına sahip oldukları için bu ülkelerde geleneksel bankaların İslami şubeleri de bulunmaktadır (Dikkaya ve Kutval, 2014: 86- 96). Katılım bankacılı̆̆ı dünyada iki temel model üzerine gelişmektedir. Bunlardan biri Körfez ülkelerinin uyguladığı muhafazakâr model diğeri ise Malezya'nın uyguladığı modeldir. Malezya, ticari bankacılıkta kullanılan tüm finansal araçlara alternatif olarak İslami finansa uygun araçlar geliştirip uygulamaktadır (Güngör, 2015: 57). Bunlardan farklı olarak 
İran'daki tüm bankalar İslami bankacılık sektöründe faaliyet göstermektedir. BAE tam olarak İslami bankacılık faaliyeti yapan bankalara sahiptir. Diğer ülkelerde ise geleneksel ve İslami bankacılık türleri ayrı olarak yer alabilmektedir. (Çelik ve Doğan, 2017: 30).

Şekil 1: Küresel İslami Bankacılık Aktiflerinin Payı (2019)

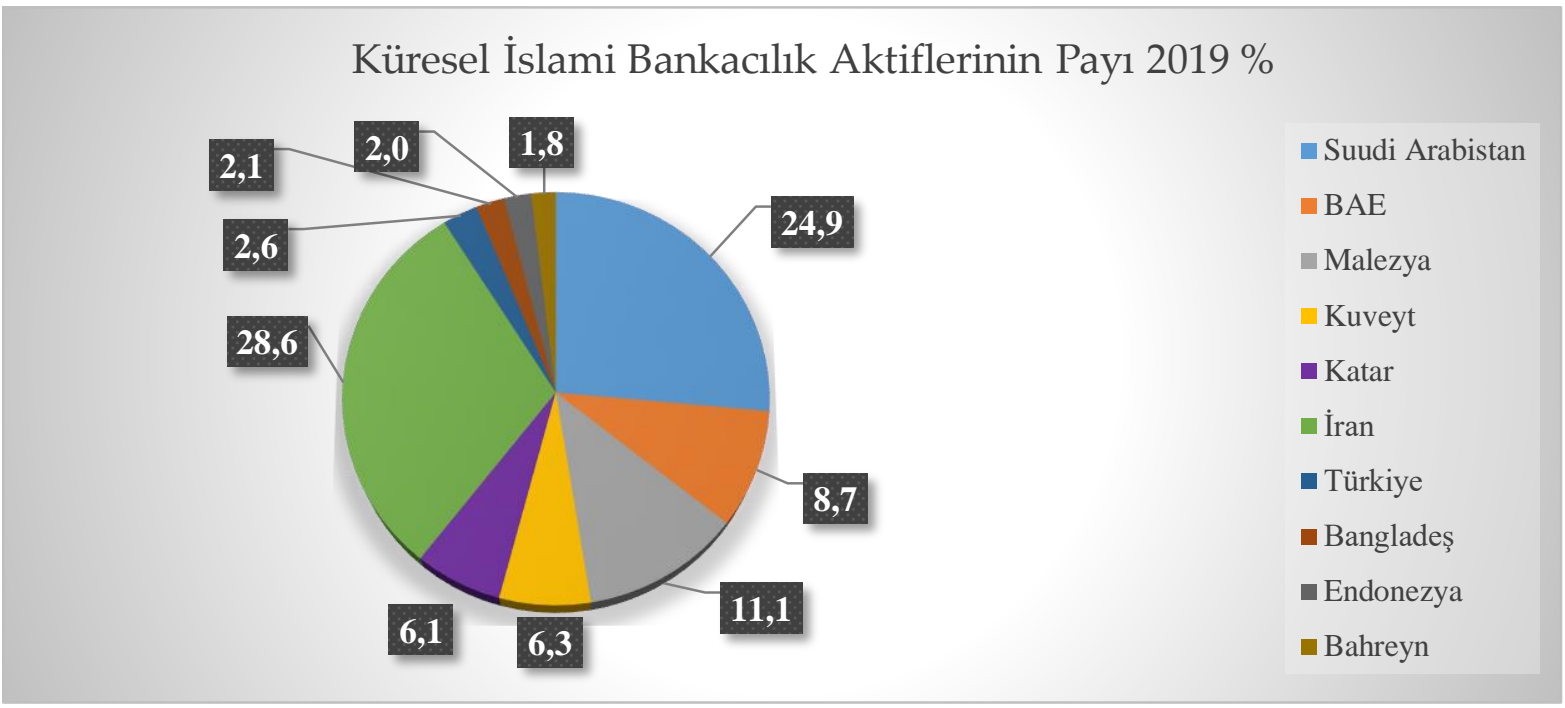

Kaynak: IFDI 2020

Şekil 2: İslami Bankacılık Toplam Aktifleri ve Banka Sayısı

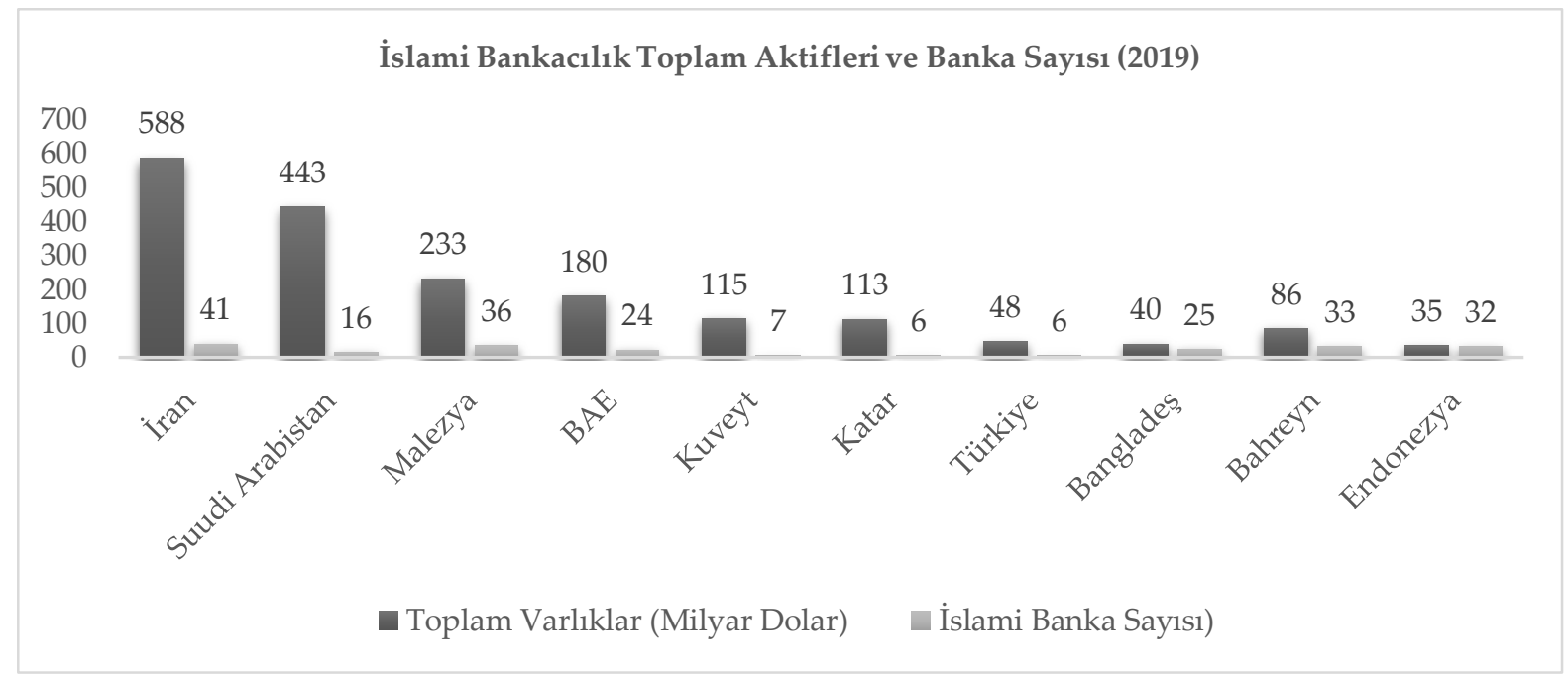

Kaynak: IFDI 2020 / ICD-REFINITIV

Şekil 1 ve Şekil 2' de İslami bankacılık aktiflerinin toplam payı, ülkelere göre dağılımı ve banka sayısı verilmiştir. En yüksek İslami bankacılık toplam aktifleri 588 milyar dolar ve \%28,6'lık pay ile İran'da bulunmaktadır. Ayrıca en fazla bankaya sahip olan da yine 41 banka ile İran'dır. İran'1 takip eden ülkeler ise sırasıyla; Suudi Arabistan (\%24,9), Malezya (\%11,1) ve BAE (\%8,7)'dir. Bangladeş ve Endonezya gibi ülkelerde İslami banka sayıları yüksek olmasına rağmen aktif toplamları diğer ülkelere göre daha düşüktür. Bahreyn 86 milyar dolar aktif toplamina sahiptir. Bahreyn'de 35 İslami banka faaliyet göstermektedir. Türkiye ise 6 adet bankası olmasına rağmen toplam aktifleri 48 milyar dolar ve payı \%2,6'dır. Bu durumda 
Türkiye'nin Bangladeş ve Endonezya gibi ülkelerden İslami bankacılık toplam aktif konusunda daha iyi durumda olduğu görülmektedir. Kuveyt ve Katar ise İslami banka sayısı az olmasına rağmen oldukça yüksek aktif toplamına sahiptir.

Şekil 3: Ülkelerin Kendi Bankacılık Sektörlerinden Aldıkları Pay (2018)

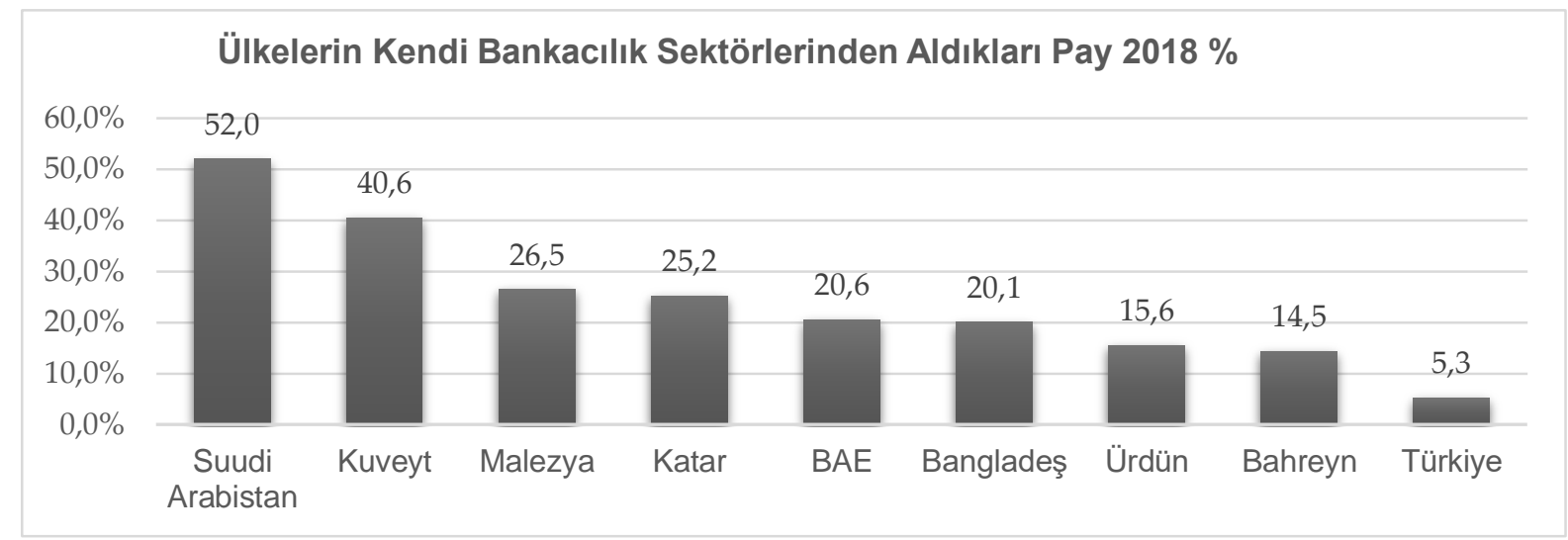

Kaynak: IFSI 2019 / Stability Report

Şekil 3'te ise ülkelerin kendi bankacılık sektörlerinden almış oldukları paylar yer almaktadır. Suudi Arabistan \%50-60 arasında bir oranla en yüksek payı alan ülkedir. İkinci sırada ise $\% 40,6$ 'lık pay alan Kuveyt bulunmaktadır. Son sırada yer alan Türkiye'nin ise kendi bankacılık sektöründen faizsiz bankaların almış olduğu pay 2018 yılında \%5,3'tür. 2019 yılında ise bu pay $\% 6,3$ oranına yükselmiştir.

Şekil 4: İslami Bankacılık Toplam Aktifleri ve Payları (2012-2019)

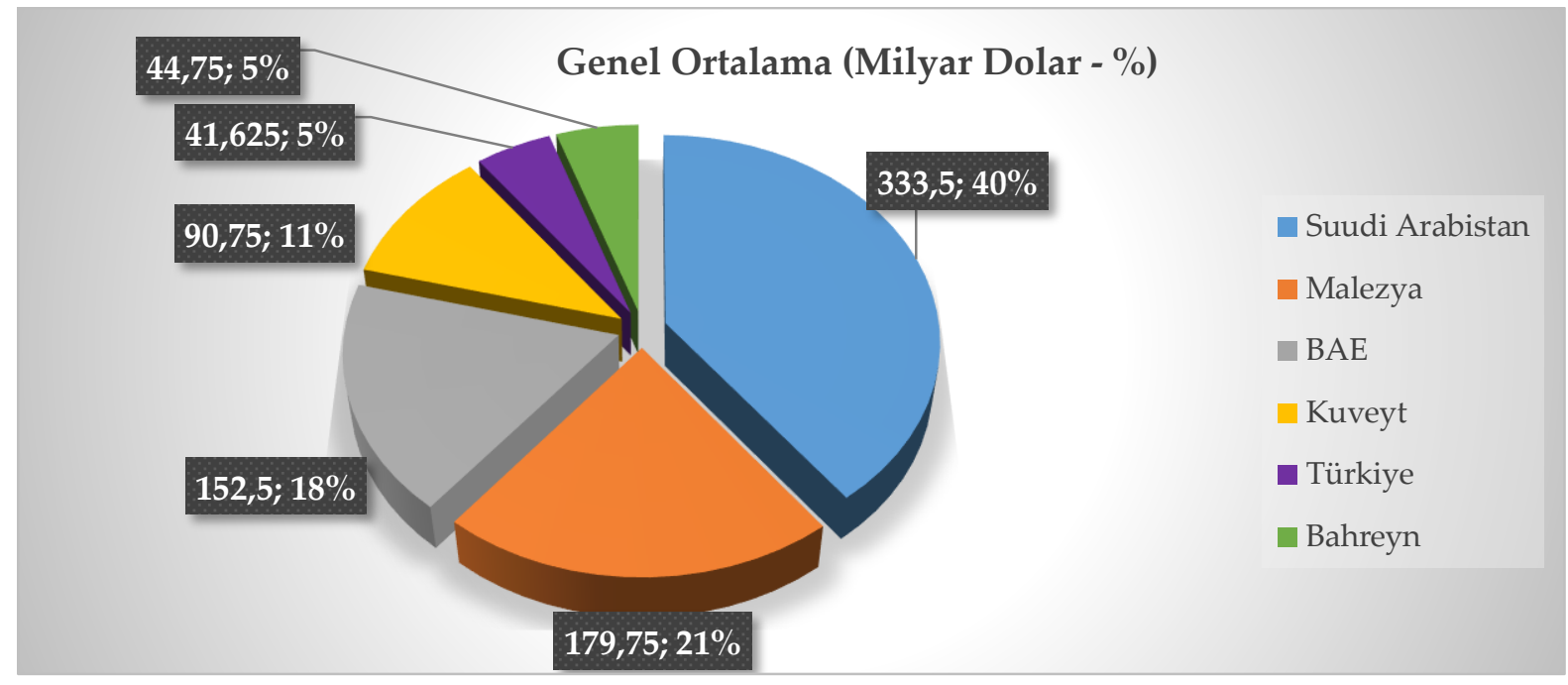

Kaynaklar: IFDI 2012-2019 / IFSB Metadata (İslamic Banking) / Banking in emerging markets / World Islamic Banking Competitevenes

Bu çalışmaya dahil edilen 6 ülkenin İslami bankacılık aktif toplamlarının 2012-2019 yılları incelendiğinde en yüksek pay Suudi Arabistan'a aittir. İkinci sırada yer alan ülke Malezya, üçüncü sırada ise Birleşik Arap Emirlikleri vardır. Kuveyt dördüncü sırada, Bahreyn beşinci sırada, Türkiye ise altıncı sırada yer almaktadır. 
Katılım bankacılığı Türkiye topraklarındaki tarihi incelendiğinde Osmanlı Devleti'nde faaliyette olan para vakıfları ön plana çıkmaktadır. Osmanlı Devleti'nde ulema, şeyhülislam ve kazaskerlerin bazıları para vakıflarının bir sakıncasının olmadığını savunurken bazıları ise buna karşı çıkmıştır. Şeyhulislam Ebussuud Efendi nakit para vakıflarının caiz olduğu fikrini savunmuş ve bu tartışmalara son vermiştir. Sonraki dönemlerde ise kanunen yasal hale getirilmiştir (Keleş H. , 2001: 193). Para vakıflarında, varlıklı kişiler elde etmiş oldukları kazançlarını veya mallarını, halk ise küçük miktarlardaki yardımlarını vakıflara aktarabilmektedir. Böylece toplanan hayırlar ile özellikle savaş dönemlerinde halkın ödediği avarız vergisi için önemli bir destek aracı olarak vakıflar kullanılmıştır. Osmanlı Devleti'ndeki Evkaf Nezareti ise vakıflardan sorumlu olan kurum olarak görev yapmıştır. 1913 yılında vakıf arazilerinin satışı dolayısıyla Evkaf Bankası kurulması kararı alınmıştır. Ancak I. Dünya Savaşı'nın meydana gelmesi nedeniyle girişim tamamlanamamıştır (Semiz, 2016: 94-95).

Türkiye Cumhuriyeti Devleti döneminde 1975 yılına kadar katılım bankacılığında herhangi bir girişim söz konusu olmamışken 1970'li yıllarda Türkiye'den Almanya'ya ve Avrupa'ya işçi göçlerinin yaşandığı bir dönemdir. Bu sebeple işçilerin tasarrufları ile kurulan işçi şirketleri organizasyonu gerçekleştirilmiştir. Bu işçi şirketleri tam anlamıla bir banka faaliyeti göstermese de halkın dini hassasiyetlerine dikkat ederek ihtiyaçların karşılanmasını sağlamıştır. 1975 yılında devletin de desteklemesiyle Devlet Sanayi İşçi Yatırım Bankası (DESIYAB) kurulmuştur. Bu bankacilık sistemi doğrudan katılım bankacıllı̆ı anlamına gelmeyip, kâr-zarar ortaklığına uygun faaliyetler göstermiştir. DESIYAB yaşanan ekonomik sıkıntılar nedeniyle faaliyetlerine 1978 yılında son vermiş ve 1988 yılında Türkiye Kalkınma Bankasına dönüştürülmüştür (Canbaz, 2018: 234).

1983 yılında ise Özel Finans Kurumları (ÖFK) faaliyete başlamıştır. Özel Finans Kurumları 2005 yılında Katılım Bankacılığı ismini alarak kapsamları genişletilmiştir. Faizsiz finansal hizmet sunan katılım bankaları reel sektöre yönelerek önemli bir ihtiyaca karşılık vermiştir (Dikkaya ve Kutval, 2014: 99-101). Türkiye'de 2020 yılı itibariyle 6 adet katılım bankası faaliyet göstermektedir. Bunlar Albaraka Türk Katılım Bankası, Kuveyt Türk Katılım Bankası, Türkiye Finans Katılım Bankası, Ziraat Katılım Bankası, Vakıf Katılım Bankası ve 2019 yılında faaliyetlerine başlayan Emlak Katılım Bankası'dır. Bununla birlikte bu katılım bankaları için düzenleyici ve destekleyici kurum vazifesinde olan Türkiye Katılım Bankaları Birliği (TKBB) faaliyetlerini sürdürmektedir.

Tablo 1: Türkiye' de Katılım Bankalarının Aktif Gelişimi ve Sektör İçindeki Payı

\begin{tabular}{|c|c|c|c|}
\hline Yıllar & $\begin{array}{c}\text { Aktif Toplami } \\
\text { (Milyon TL) }\end{array}$ & Değişim \% & Sektör Pay1 \% \\
\hline $\mathbf{2 0 1 5}$ & 120.252 & 15,27 & 5,1 \\
\hline $\mathbf{2 0 1 6}$ & 132.874 & 10,5 & 4,9 \\
\hline $\mathbf{2 0 1 7}$ & 160.136 & 20,5 & 4,9 \\
\hline $\mathbf{2 0 1 8}$ & 206.806 & 29,1 & 5,3 \\
\hline $\mathbf{2 0 1 9}$ & 284.459 & 37,5 & 6,3 \\
\hline
\end{tabular}

Kaynak: TKKB/Katılım Bankaları 2019 
Tablo 1'de yer alan Türkiye'de katılım bankalarının aktif gelişimi ve sektör içindeki payı incelendiğinde katılım bankalarının aktif toplamlarındaki değişimin yıllara göre arttığ1 görülmektedir. 2016 yılında aktif toplamlarının azalmış olması dolaysıyla sektör payında da bir gerilemeye sebep olmuş ancak 2018 ve 2019 yıllarında toparlanma yaşandığ anlaşılmaktadır. Türkiye'de katılım bankacılığı mevcut konvansiyonel bankacılık sektöründen 2019 yılı itibariyle \%6,3 ‘lük bir pay almaktadır. Geleceğe yönelik hedefler arasında katılım bankacılığı sektörünü \%15 düzeyine taşıyabilmek vardır.

Bu çalışmada IFSI 2019 raporunda ilk 10 sırada yer alan ülkelerden verilerine düzenli olarak ulaşılabilen ve raporlama tarihleri Türkiye ile benzerlik gösteren ülkelerin (Suudi Arabistan, Malezya, BAE, Kuveyt, Türkiye, Bahreyn) 2012-2019 dönemine ait verileri TOPSIS yöntemi ile analiz edilerek finansal performans sıralaması oluşturulmuştur. Çalışmada bu 6 ülkede faaliyet gösteren katılım bankalarının ve ülkelerin finansal performans sıralaması oluşturulurken 11 adet finansal orandan kullanılmıştır. Literatürde yer alan çalışmalara göre seçilen ülkeler, bankalar, finansal oranlar ve banka sayıları yönünden farklılıklar oluşmaktadır. Çalışmanın temel amacı 6 ülkede faaliyet gösteren bankaların ve bu 6 ülkenin finansal performans sıralamalarını oluşturmak ve IFSI 2019 raporunda yer alan Küresel İslami Bankacılık Toplam Aktif Payları sıralamasını, İslami bankacılık finansal performans sıralaması ile karşılaştırmaktır. Böylece literatürde yer alan çalışmalarda daha önce rastlanmamış bir karşılaştırma yapılmasının amaçlanması çalışmanın özgün değerini oluşturmaktadır.

\section{Bankacılık Sektöründe Finansal Performans}

Herhangi bir kurumun, işletmenin, sistemin, bir grubun veya bir bireyin belirlemiş olduğu amaçlarına ulaşma noktasında planlı olarak sergilemiş olduğu nitel veya nicel çabaların düzeyini gösteren kavram performans olarak ifade edilmektedir (Esmer ve Bağcl, 2016: 18). Performansın mutlak ve nispi olarak ölçülebilmesi için ortaya konulmuş çabaların, organizasyonun veya faaliyetin değerlendirilmesi gerekmektedir (Özer, 2009: 4).

İşletmelerde performans ölçümü ise işletmenin kontrol mekanizmasının yerine getirilmesi ile ilgilidir. İşletme tarafından önceden belirlenmiş olan hedeflere ne ölçüde ve nasıl ulaşıldığının veya ulaşılmadığının kontrol edilebildiği bir araçtır (Coşkun, 2005: 4). Bir işletmenin ne kadar verimli ve etkin olarak çalıştı̆̆ bazı kriterlere yönelik gerçekleştirilen performans ölçümü neticesinde ortaya çıkmaktadır (Arıçelik, 2010: 13). İşletmelerde performans ölçümü yapılırken finansal veya finansal olmayan kriterler kullanılabilmektedir. İşletme yöneticileri veya dış paydaşlar işletmenin performansını değerlendirirken genellikle finansal kriterleri kullanmaktadırlar (Coşkun, 2005: 5). Finansal performans ölçümünde işletmenin faaliyet yapısı, kaynak yapısı, likiditesi, kârlılığı gibi kriterler dikkate alınmaktadır (Yılmaz ve Yakut, 2021: 6).

Bankacılık sektörü ekonomik sistemde gerçekleştirdiği faaliyetler nedeniyle önemli bir yere sahiptir. Bankalar çeşitli sektörlerde yer alan işletmeler için fon sağlamakta ve tüm bankacılık faaliyetlerini gerçekleştirmektedirler (Yılmaz ve Yakut, 2021: 8). Bankacılıkta finansal performans ölçümü yapılırken genellikle finansal veriler ve kârlılık göstergelerine 
odaklanılmaktadır (Arıçelik, 2010: 24). Bankacılıkta finansal performans ölçüm kriterleri sermaye yeterlilik, aktif kalitesi, likidite, kârlılık, gelir-gider yapısı ve bilanço oranlarından oluşmaktadır (Yılmaz ve Yakut, 2021: 8-14). Bu çalışmada da sermaye yeterlilik, bilanço yapısı, aktif kalitesi, likidite ve kârlılık oranlarından oluşan 11 adet finansal oran kriter olarak kullanılarak finansal performans ölçümü yapılmıştır.

\section{Literatür Taraması}

Tablo 2: Literatür Taraması

\begin{tabular}{|c|c|c|c|c|}
\hline $\begin{array}{c}\text { Yazarlar/Yayın } \\
\text { Y1lı }\end{array}$ & Dönem & Ülke & Yöntem & Sonuç \\
\hline $\begin{array}{l}\text { Sufian ve Noor } \\
\qquad(2009)\end{array}$ & $\begin{array}{l}2001- \\
2006\end{array}$ & $\begin{array}{c}\text { MENA } \\
\text { Bölgesi ve } \\
\text { Asya Ülkeleri }\end{array}$ & $\begin{array}{c}\text { Veri } \\
\text { Zarflama } \\
\text { Analizi }\end{array}$ & $\begin{array}{l}\text { Çalışmanın sonucunda MENA bölgesindeki } \\
\text { İslami bankaların Asya'da faaliyet gösteren } \\
\text { İslami bankalara göre ortalama teknik } \\
\text { verimliliğinin daha yüksek olduğu saptanmıştır. } \\
\text { Verimlilik sırasına göre MENA bölgesindeki } \\
\text { bankaların dünya lideri olduğu tespit edilmiştir. }\end{array}$ \\
\hline $\begin{array}{c}\text { Yayar ve } \\
\text { Baykara (2012) }\end{array}$ & $\begin{array}{l}2005- \\
2011\end{array}$ & Türkiye & TOPSIS & $\begin{array}{l}\text { Türk katılım bankalarının etkinlik ve verimlilik } \\
\text { düzeylerini tespit etmek amacıyla } \\
\text { gerçekleştirilen çalışmanın sonucunda Kuveyt } \\
\text { Türk Katılım Bankasının sukuk ürününü } \\
\text { kullanmaya başladıktan sonra en verimli banka } \\
\text { sıralamasında yükseldiği tespit edilmiştir. }\end{array}$ \\
\hline $\begin{array}{c}\text { Kamaruddin ve } \\
\text { Mohd (2013) }\end{array}$ & $\begin{array}{l}2007- \\
2011\end{array}$ & Malezya & CAMELS & $\begin{array}{l}\text { Malezya'daki İslami bankaların ve geleneksel } \\
\text { bankaların performansının analiz edildiği } \\
\text { çalışmanın sonucunda zaman içerisinde iki } \\
\text { sistemin birbirine paralel olarak performans } \\
\text { sergilediği saptanmıştır. }\end{array}$ \\
\hline $\begin{array}{l}\text { Saldanlı ve } \\
\text { Sirma (2014) }\end{array}$ & $\begin{array}{l}2008- \\
2012\end{array}$ & Türkiye & TOPSIS & $\begin{array}{l}\text { Çalışmalarında TOPSIS yönteminin işletmelerin } \\
\text { performanslarında bir gösterge olarak } \\
\text { kullanılabilirliğini değerlendirmişlerdir. İlk } \\
\text { uygulamada BIST-100 endeksindeki imalat } \\
\text { sanayi işletmelerinin 2008-2012 yıllarındaki } \\
\text { verileri kullanılmıştır. İkinci uygulamada ise } \\
\text { BIST'da işlem gören bankaların yine 2008-2012 } \\
\text { yıllarındaki veriler kullanılmıştır. Çalışmanın } \\
\text { sonucunda her iki uygulamada da işletmenin } \\
\text { yıllık gelirleri ile TOPSIS sonuçları arasında } \\
\text { anlamlı ilişki gözlenmemiştir. }\end{array}$ \\
\hline $\begin{array}{c}\text { Ghasempour ve } \\
\text { Salamı (2016) }\end{array}$ & $\begin{array}{l}\text { Mart } \\
2015\end{array}$ & İran & $\begin{array}{l}\text { AHP Hibrid } \\
\text { Yaklaşımı, } \\
\text { TOPSIS ve } \\
\text { CAMELS }\end{array}$ & $\begin{array}{l}\text { İ́an özel bankalarının performanslarının } \\
\text { değerlendirildiği çalışmada sermaye yeterliliği, } \\
\text { varlık kalitesi, yönetim kabiliyeti, kazanç, likidite } \\
\text { ve piyasa riskine duyarlılık gibi faktörler } \\
\text { verimlilik ve sağlamlığı ölçmek için } \\
\text { kullanılmıştır. Çalışmanın sonucunda en iyi } \\
\text { performansı sergileyen bankaların Pasargad } \\
\text { Bank, Khavarmione, Karafain, Sina ve Ansar } \\
\text { olduğu belirlenmiştir. }\end{array}$ \\
\hline
\end{tabular}




\begin{tabular}{|c|c|c|c|c|}
\hline $\begin{array}{c}\text { Wanke, Azad ve } \\
\text { Barros (2016) }\end{array}$ & $\begin{array}{l}2009- \\
2016\end{array}$ & Malezya & $\begin{array}{l}\text { TOPSIS ve } \\
\text { Sinir Ağları } \\
\text { Yaklaşımı }\end{array}$ & $\begin{array}{l}\text { Malezya'daki İslami bankalarının verimliliğini } \\
\text { ölçmeyi amaçlayan çalışmada iki aşamalı bir } \\
\text { yaklaşım uygulanmıştır. İkinci aşamada TOPSIS } \\
\text { sonuçları ile birleştirilmiştir. Çalışma 2009-2016 } \\
\text { yıllarında faaliyet gösteren } 16 \text { banka üzerinde } \\
\text { uygulanmıştır. Çalışmanın sonucunda maliyet } \\
\text { yapısı ile ilgili değişkenlerin verimliliği olumsuz } \\
\text { yönde etkilediği sonucuna ulaşılmıştır. Ayrıca } \\
\text { Malezya İslami bankacılığı yabancı bankalara } \\
\text { kültürel ve düzenleyici engeller getirdiği için } \\
\text { verimlilik düzeylerini düşürdüğü saptanmıştır. }\end{array}$ \\
\hline $\begin{array}{c}\text { Wanke, Hassan } \\
\text { ve Gavião } \\
(2017)\end{array}$ & $\begin{array}{l}2010- \\
2013\end{array}$ & $\begin{array}{l}\text { ASEAN } \\
\text { Bölgesi }\end{array}$ & $\begin{array}{c}\text { CAMELS ve } \\
\text { TOPSIS }\end{array}$ & $\begin{array}{l}\text { Çalışmada } 88 \text { ASEAN (Association of Southeast } \\
\text { Asian Nations) bankasının performanslarını } \\
\text { ölçmek için bütünleşik iki yaklaşım } \\
\text { kullanılmıştır. Çalışmanın sonucunda kültürel ve } \\
\begin{array}{llr}\text { düzenleyici engellerin yabancı kökenli } \\
\text { bankalarda verimliliği düşürdüğü tespit } \\
\text { edilmiştir. }\end{array}\end{array}$ \\
\hline $\begin{array}{l}\text { Alsu, Taşdemir } \\
\text { ve Kallo (2018) }\end{array}$ & $\begin{array}{l}2009- \\
2015\end{array}$ & $\begin{array}{c}\text { Suudi } \\
\text { Arabistan, } \\
\text { BAE, Kuveyt, } \\
\text { Katar, Ürdün } \\
\text { ve Türkiye }\end{array}$ & TOPSIS & $\begin{array}{l}\text { Çalışmada bankaların 2009-2015 yıllarına ait } \\
\text { finansal verileri kullanılmıştır. Çalışmanın } \\
\text { sonucunda Suudi Arabistan ve Katar ülkelerine } \\
\text { ait katılım bankalarının performans } \\
\text { sıralamasında üst sıralarda yer alırken } \\
\text { Türkiye'deki katılım bankaları orta sıralarda yer } \\
\text { almıştır. }\end{array}$ \\
\hline $\begin{array}{l}\text { Tetik ve Şahin } \\
\text { (2020) }\end{array}$ & $\begin{array}{l}2011- \\
2019\end{array}$ & Türkiye & TOPSIS & $\begin{array}{l}\text { Çalışmada 2011-2019 yıllarına ait veriler } \\
\text { kullanılarak Türkiye'de faaliyet gösteren } 7 \\
\text { katılım bankasının finansal performansları } \\
\text { TOPSIS yöntemi ile değerlendirilmiştir. } \\
\text { Çalışmada } 7 \text { adet finansal oran kullanılmıştır. } \\
\text { Çalışma sonuçlarına göre en yüksek finansal } \\
\text { performansa sahip olan banka Türkiye Finans } \\
\text { Katılım Bankası, ikinci sırada Albaraka Türk } \\
\text { Katılım Bankası, üçüncü sırada ise Kuveyt Türk } \\
\text { Katılım Bankası yer almıştır. }\end{array}$ \\
\hline Yetiz (2021) & $\begin{array}{l}2016- \\
2019\end{array}$ & Türkiye & TOPSIS & $\begin{array}{l}\text { Çalışmada Türkiye' de faaliyet gösteren } 5 \text { katılım } \\
\text { bankasının finansal performansları TOPSIS } \\
\text { yöntemi ile değerlendirilerek risk yönetimi } \\
\text { politikaları incelenmiştir. Çalışmada 2016-2019 } \\
\text { yıllarını kapsayan } 12 \text { finansal oran kullanılmıştır. } \\
\text { Çalışmanın sonucunda, Vakıf Katılım Bankasının } \\
2016 \text { yılında, Kuveyt Türk Katılım Bankasının } \\
2017 \text { yılında, Türkiye Finans Katılım Bankasının } \\
\text { ise } 2018 \text { ve } 2019 \text { yıllarında yüksek finansal } \\
\text { performans sergiledikleri tespit edilmiştir. }\end{array}$ \\
\hline
\end{tabular}

Literatürde yer alan çalışmalarda İslami bankaların finansal performansları değerlendirilirken genellikle Veri zarflama Analizi, TOPSIS yöntemi, sinir ağları yaklaşımı, CAMELS analizi gibi yöntemler veya AHP ve TOPSIS yöntemleri birlikte kullanılmıştır. Yayar ve Baykara (2012) 
çalışmalarında Türk katılım bankalarının, Alsu, Taşdemir ve Kallo (2018) ise çalışmalarında uluslararası İslami bankaların finansal performans sıralamalarını oluştururken TOPSIS yöntemi kullanmışlardır. Bu çalışmada ise 6 ülkede faaliyet gösteren İslami bankaların ve ülkelerin sıralaması oluşturulurken TOPSIS yöntemi kullanılmıştır. Ancak bu çalışma seçilen ülkeler, bankalar, finansal oranlar açısından farklılıklar göstermektedir. Ayrıca bu çalışmada ülkelerin IFSI 2019 raporunun küresel İslami bankacılık toplam aktif payları sıralaması ile bu ülkelerin İslami bankacılık finansal performanslarını karşılaştırmak amaçlanmıştır. Bu amaca uygun olarak çalışmaya dahil edilen 6 ülkede yer alan bankaların finansal verileri ile ülke ortalamaları oluşturularak TOPSIS yönteminin uygulaması yapılmıştır. Literatürde böyle bir karşılaştırmaya rastlanmamıştır.

\section{Veri Seti ve Yöntem}

Bu çalışmada yer alan ülkelerde faaliyet gösteren İslami bankaların verilerine her bankanın yayınlamış olduğu yılsonu faaliyet raporlarından ulaşılmıştır. Türkiye'deki katılım bankalarına ait verilere ise TKBB 'den ulaşılmıştır. Çalışmada seçilen bankaların finansal performansı ölçülürken 2012-2019 yıllarına ait veriler kullanılmıştır. Uygulamaya dâhil edilen bankaların listesi Tablo 4 'te verilmiştir. TOPSIS uygulamasından verimli ve etkin bir sonuç alınabilmesi için çalışmanın kapsamında yer alan yıllara ait verilerin eksiksiz olarak bulunması gerekmektedir. Bu nedenle verilerine ulaşılamayan ve finansal bitiş yılları Türkiye' deki bankalardan farklı olan bankalar seçilmemiştir.

Tablo 3: Çalışmada Yer Alan Bankaların Listesi

\begin{tabular}{|c|c|}
\hline MALEZYA & BAHREYN \\
\hline $\begin{array}{l}\text { CIMB Islamic Bank Berhad (CIMB) } \\
\text { Affin Islamic Bank Berhad (AIBB) } \\
\text { Public Islamic Bank Berhad (PIBB) } \\
\text { Bank Rakyat Malaysia Berhad (BR) }\end{array}$ & $\begin{array}{c}\text { Al Salam Islamic Bank Bahrain (ASBB) } \\
\text { Al Baraka Islamic Bank Berhad (ABIB) } \\
\text { Bahrain Islamic Bank (BISB) }\end{array}$ \\
\hline BİRLEŞIK ARAP EMİRLIKLERI & KUVEYT \\
\hline $\begin{array}{c}\text { Dubai Islamic Bank (DIB) } \\
\text { Sharjah Islamic Bank (SIB) } \\
\text { Emirates Islamic Bank (EIB) } \\
\text { Abu Dhabi Islamic Bank (ADIB) }\end{array}$ & $\begin{array}{c}\text { Ahli United Bank (AUB) } \\
\text { Boubyan Bank (BB) } \\
\text { Kuwait Finance House (KFH) }\end{array}$ \\
\hline SUUDİ ARABISTAN & TÜRKİYE \\
\hline $\begin{array}{c}\text { Bank Al Jazira (BAJ) } \\
\text { Al Rajhi Bank (ARB) } \\
\text { Samba Bank (SB) } \\
\text { Banque Saudi Fransi (BSF) }\end{array}$ & $\begin{array}{l}\text { Al Baraka Türk Katılım Bankası (ATKB) } \\
\text { Kuveyt Türk Katılım Bankası (KTKB) } \\
\text { Türkiye Finans Katılım Bankası (TFKB) }\end{array}$ \\
\hline
\end{tabular}


$\mathrm{Bu}$ çalışmada katılım bankalarının uluslararası boyutta finansal performansları karşılaştırılırken Sermaye Yeterlilik, Bilanço Yapısı, Aktif Kalitesi, Likidite ve Kârlılık oranları kullanılmıştır. Bu oranlar TOPSIS yöntemi uygulanmasının kriterlerini oluşturmaktadır. 21 katılım bankasına ait 8 yıllık finansal veriler ve 11 farklı finansal oran kullanılmıştır. Çalışmada finansal oranlar eşit olarak ağırlıklandırılmış ve her bir kriterin ağırlığı 0,091 (1/11) olarak belirlenmiştir. Tablo 2' de çalışmada kullanılan finansal oranlara ve ağırlık değerlerine yer verilmiştir.

Tablo 4: Finansal Performans Değerlendirmesinde Çalışmada Kullanılan Finansal Oranlar ve Ağırlıkları

\begin{tabular}{|c|c|c|c|}
\hline Kod & Finansal Oranlar & Mak - Min. & Ăğrlık \\
\hline 1 & Öz Kaynaklar / Toplam Aktifler & Maksimum & 0,091 \\
\hline 2 & $\begin{array}{c}\text { (Öz Kaynaklar - Duran Aktifler) / Toplam } \\
\text { Aktifler }\end{array}$ & Maksimum & 0,091 \\
\hline 3 & Toplam Toplanan Fonlar / Toplam Aktifler & Maksimum & 0,091 \\
\hline 4 & Finansal Varlıklar / Toplam Aktifler & Minimum & 0,091 \\
\hline 5 & Toplam Krediler ve Alacaklar / Toplam & Aktifler & 0,091 \\
\hline 6 & Toplam Krediler ve Alacaklar / Toplam & Moplanan Fonlar & 0,091 \\
\hline 7 & $\begin{array}{r}\text { Takipteki Krediler (Brüt) / Toplam Krediler ve } \\
\text { Alacaklar }\end{array}$ & Minimum & 0,091 \\
\hline 8 & Duran Aktifler / Toplam Aktifler & Minimum & 0,091 \\
\hline 9 & Likit Aktifler / Toplam Aktifler & Maksimum & 0,091 \\
\hline 10 & Net Dönem Kârı (Zararı) / Toplam Aktifler & Maksimum & 0,091 \\
\hline 11 & Net Dönem Kârı (Zararı) / Öz Kaynaklar & Maksimum & 0,091 \\
\hline Toplam & $\quad$ & & $\mathbf{1}$ \\
\hline
\end{tabular}

Çalışmada genel performans sıralaması için uygulama yapılırken bankaların finansal oranlarının tüm yıllar için ortalaması alınmıştır. TOPSIS uygulaması gerçekleştirilirken eşit ağırlıklandırılma yapılmış $(1 / 11=0,091)$ ve tüm yıllar içerisinde başarılı olan banka alternatifler arasından seçilmiştir.

Çalışmanın son aşamasında ülkelerin yıllar içerisindeki finansal oranlarının ortalaması alınarak TOPSIS yöntemi uygulanmış ve IFSI 2019 raporunun sıralaması ile karşılaştırılmıştır. $\mathrm{Bu}$ uygulama gerçekleştirilirken eşit ağırlıklandırma $(1 / 11=0,091)$ yapılmış ve alternatifler sıralanmıştır.

Bu çalışmada katılım bankalarının finansal performansları değerlendirilirken TOPSIS yöntemi kullanılmıştır. Uygun çözümün belirlenebilmesi için Hawang ve Yoon tarafından 1981 yılında geliştirilen TOPSIS (Technique for Order Preference by Similarity to Ideal Solution) yöntemi 
çok kriterli karar verme yöntemlerinden biridir (Dymova, Sevastjanov, \& Tikhonenko, 2013: 149). TOPSIS yöntemi yazında pek çok çalışmada kullanılmakla birlikte firmaların finansal performanslarının TOPSIS yöntemi ile karşılaştırılmasında da kullanılmıştır. TOPSIS yönteminde amaç seçeneklerin pozitif ideal çözüme olan uzaklığının az, negatif ideal çözüme olan uzaklığının daha fazla olmasıdır. Pozitif ideal çözüme en yakın seçenek en iyi karar seçeneğini oluşturmaktadır. TOPSIS yönteminde en ideal çözüm maliyetin minimize, faydanın ise maksimize edildiği seçeneğe ulaşmaktır (Özbek, 2017: 201). TOPSIS yönteminin uygulamaya geçirilebilmesi için en az iki karar seçeneğinin bulunması gerekmektedir. Aşağıda yer verilen adımlar takip edilerek en uygun seçenek belirlenmektedir.

Bu çalışmada TOPSIS Yöntemi kullanılırken aşağıdaki adımlar takip edilmiştir:

Adım 1: Karar Matrisinin Oluşturulması: TOPSIS yönteminin ilk adımını karar matrisleri oluşturmaktadır. Oluşturulan $\mathrm{m}^{*} \mathrm{n}$ şeklindeki karar matrislerinde " $\mathrm{m}$ " karar matrisinin alternatiflerini göstermekte " $n$ " ise karar matrisinin kriterlerini göstermektedir. Bu çalışmada alternatifler bankaları ve kriterler finansal oranları göstermektedir. Oluşturulan karar matrisi (1) numaralı eşitlik ile gösterilmektedir.

$$
D_{i j}=\left[\begin{array}{cccc}
d_{11} & d_{12} & \cdots & d_{1 n} \\
d_{21} & d_{22} & \cdots & d_{2 n} \\
\cdots & \cdots & \cdots & \cdots \\
d_{i 1} & d_{i 2} & \cdots & d_{i n} \\
\cdots & \cdots & \cdots & \cdots \\
d_{m 1} & d_{m 2} & \cdots & d_{m n}
\end{array}\right]
$$

Adım 2: Standart Karar Matrisinin Oluşturulması: Standart karar matrisi oluşturulurken 2 numaralı formülden yararlanılmaktadır. Bu formülde karar matrisinin her bir hücresindeki değerlerin karelerinin toplamının karekökü alınır ve her bir hücre tekrar bu değere bölünerek standart karar matrisi oluşturulur. Oluşturulan standart karar matrisi 4 numaralı eşitlikte gösterilmiştir.

$$
\begin{aligned}
& \forall d_{i j} \neq 0: r_{i j}=\frac{d_{i j}}{\sqrt{\sum_{k=1}^{m} d_{k j}^{2}}} \\
& \forall d_{i j}=0: r_{i j}=0 ; \forall_{i}=1, \ldots, m, \forall_{i}=1, \ldots, n \\
& R_{i j}=\left[\begin{array}{cccc}
r_{11} & r_{12} & \cdots & r_{1 n} \\
r_{21} & r_{22} & \cdots & r_{2 n} \\
\cdots & \cdots & \cdots & \cdots \\
r_{i 1} & r_{i 2} & \cdots & r_{i n} \\
\cdots & \cdots & \cdots & \cdots \\
r_{m 1} & r_{m 2} & \cdots & r_{m n}
\end{array}\right]
\end{aligned}
$$

Adım 3: Ağırlıklı Standart Karar Matrisinin Oluşturulması: TOPSIS yönteminin üçüncü adımında belirlenen kriter ağırlıklarının standart karar matrisindeki her bir hücre ile çarpılması sonucu ağırlıklı standart karar matrisi meydana getirilir. Kriterlerde ağırlıklandırma yapılırken toplamda ağırlık değerinin 1 olmasına dikkat edilir. Bu çalışmada 
eşit ağırlıklandırma yapılmıştır. Bu işlemin sonucunda ağırlıklı standart karar matrisi oluşturulur. Ağırlıklı standart karar matrisi 5 numaralı eşitlikte gösterilmiştir.

$$
V_{i j}=\left[\begin{array}{cccc}
w_{1} r_{11} & w_{2} r_{12} & \cdots & w_{n} r_{1 n} \\
w_{2} r_{21} & w_{2} r_{22} & \cdots & w_{n} r_{2 n} \\
\cdot & \cdot & \cdot & \cdot \\
\cdot & \cdot & \cdot & \cdot \\
\cdot & \cdot & \cdot & \cdot \\
w_{1} r_{m 1} & w_{2} r_{m 2} & \cdots & w_{n} r_{m n}
\end{array}\right]
$$

Adım 4: İdeal ( $\left.A^{*}\right)$ ve Negatif İdeal (A-) Çözümlerin Oluşturulması: Yöntemin dördüncü adımında kriterler için belirlenen maksimum ve minimum değerler ile ideal $\left(\mathrm{A}^{*}\right)$ ve negatif ideal (A-) çözüm kümeleri oluşturulur. Bu çözüm kümeleri oluşturulurken ağırlıklı standart karar matrisindeki en yüksek değerler maksimum, en düşük değerler ise minimum olarak belirlenir. İdeal çözüm kümesinde kriterlerin maksimum ve minimum durumuna göre seçim yapılır. Negatif ideal çözüm kümesi elde edilirken de ideal çözümün tam tersi seçim yapılır. İdeal çözümler (6) ve (7) numaralı eşitlikler çözümlenerek hesaplanmaktadır.

$$
\begin{aligned}
& A^{*}=\left\{\left(\begin{array}{c}
\left.\max _{i} V_{i j} \mid j \in J\right) \\
\min _{i} V_{i j} \mid j \in J^{\prime}
\end{array}\right) i=1, \ldots, m\right\} \\
& A^{*}=\left\{v_{1}^{*}, v_{2}^{*}, \cdots, v_{j}^{*}, \cdots, v_{n}^{*}\right\} \\
& A^{-}=\left\{\left(\min _{i} V_{i j} \mid j \in J\right),\left(\max _{i} V_{i j} \mid j \in J^{\prime}\right) i=1, \ldots, m\right\} \\
& A^{-}=\left\{v_{1}^{-}, v_{2}^{-}, \cdots, v_{j}^{-}, \cdots, v_{n}^{-}\right\} \\
& J \cap J^{\prime}=\emptyset \wedge J \cup J^{\prime}=\{1, \ldots, n\}
\end{aligned}
$$

Adım 5: Ayrım Ölçülerinin Hesaplanması: TOPSIS yönteminin beşinci adımı olan ayrım ölçüleri hesaplanırken Öklid uzaklık mantı̆̆ından faydalanılarak belirlenen formüller aracılığıyla pozitif ideal çözüme ve negatif ideal çözüme olan uzaklıklar hesaplanır. TOPSIS yönteminde her bir seçenek $A_{i}$ için ideal ayrım $S_{i}^{*}$ ve negatif ideal ayrım $S_{i}^{-}$olarak adlandırılan iki ayrım ölçüsü oluşmaktadır. J seçeneğinin pozitif ideal çözüme uzaklığı $S_{i}^{*}$, (8) numaralı eşitlik ve negatif ideal çözümden uzaklığı $S_{i}^{-}$(9) numaralı eşitlik yardımıyla çözümlenmektedir. Ağırlıklı standart karar matrisindeki değerlerden pozitif ideal çözüm kümesinin her bir sütunundaki değerler çıkarılarak ideal ayrım ölçüleri bulunur. Ağırlıklı standart karar matrisindeki değerler negatif ideal çözüm kümesindeki değerlerden çıarılarak negatif ideal ayrım ölçüleri hesaplanır. Son olarak her satırın toplam değeri alınarak karekökü hesaplanir.

$$
\begin{gathered}
S_{i}^{*}=\sqrt{\sum_{j=1}^{n}\left(v_{i j}-v_{j}^{*}\right)^{2}} \quad \forall_{i}=1, \ldots, m \\
S_{i}^{-}=\sqrt{\sum_{j=1}^{n}\left(v_{i j}-v_{j}^{-}\right)^{2}} \quad \forall_{i}=1, \ldots, m
\end{gathered}
$$


Adım 6: İdeal Çözüme Göreli Yakınlığın Hesaplanması: Son adımda ideal $S_{i}^{*}$ ve negatif deal $S_{i}^{-}$ayrım ölçülerinin pozitif ideal çözüme yakınlıkları hesaplanır. Bu hesaplama (10) numaralı eşitlikte gösterilmiştir. Pozitif ideal çözüme en yakın mesafede bulunan seçenek için karar verilir. $C_{i}^{*}$ değerleri 0 ile 1 arasında bir değer alır. 1'e olan yakınlık pozitif ideal çözüm noktasında 0 'a olan yakınlık ise negatif ideal çözüm noktasında olduğunu belirtmektedir.

$$
C_{i}^{*}=\frac{s_{i}^{-}}{s_{i}^{-}+s_{i}^{*}} \quad 0 \leq C_{i}^{*} \leq \forall_{i}=1, \ldots, m
$$

$C_{i}^{*}, 0 \leq C_{i}^{*} \leq 1$ aralığında bir değer alır ve $C_{i}^{*}=1, i$. Karar seçeneğinin pozitif ideal çözüm noktasında, $C_{i}^{*}=0$ ise karar seçeneğinin negatif ideal çözüm noktasında bulunduğu anlamına gelir.

\section{Bulgular}

Çalışmada TOPSIS yönteminin uygulanmasında ilk aşama olan karar matrislerine yönelik örnek tablo 2012 yılı için Tablo 5'te verilmiştir. Geri kalan tablolar Ekler bölümünde yer almaktadir.

Tablo 5: 2012 Y1lı Bankaların Karar Matrisi

\begin{tabular}{|l|c|c|c|c|c|c|c|c|c|c|c|}
\hline \multicolumn{1}{|c|}{ 2012 } & $\mathbf{1}$ & $\mathbf{2}$ & $\mathbf{3}$ & $\mathbf{4}$ & $\mathbf{5}$ & $\mathbf{6}$ & $\mathbf{7}$ & $\mathbf{8}$ & $\mathbf{9}$ & $\mathbf{1 0}$ & $\mathbf{1 1}$ \\
\hline CIMB & 0,05 & 0,04 & 0,92 & 0,19 & 0,65 & 0,70 & 0,01 & 0,00 & 0,31 & 0,01 & 0,17 \\
\hline AIBB & 0,06 & 0,06 & 0,93 & 0,17 & 0,44 & 0,47 & 0,03 & 0,00 & 0,54 & 0,01 & 0,11 \\
\hline PIBB & 0,08 & 0,08 & 0,90 & 0,12 & 0,69 & 0,77 & 0,01 & 0,00 & 0,28 & 0,01 & 0,18 \\
\hline BR & 0,13 & 0,11 & 0,79 & 0,23 & 0,70 & 0,88 & 0,03 & 0,02 & 0,17 & 0,02 & 0,17 \\
\hline ASBB & 0,22 & 0,21 & 0,76 & 0,22 & 0,35 & 0,46 & 0,03 & 0,01 & 0,31 & 0,01 & 0,05 \\
\hline ABIB & 0,12 & 0,06 & 0,86 & 0,28 & 0,48 & 0,56 & 0,17 & 0,06 & 0,20 & $-0,01$ & $-0,06$ \\
\hline BISB & 0,08 & $-0,07$ & 0,90 & 0,13 & 0,50 & 0,55 & 0,44 & 0,16 & 0,21 & $-0,04$ & $-0,52$ \\
\hline DIB & 0,11 & 0,06 & 0,77 & 0,14 & 0,58 & 0,76 & 0,11 & 0,05 & 0,20 & 0,01 & 0,11 \\
\hline SIB & 0,24 & 0,20 & 0,64 & 0,05 & 0,59 & 0,91 & 0,08 & 0,05 & 0,23 & 0,02 & 0,10 \\
\hline EIB & 0,07 & 0,07 & 0,77 & 0,08 & 0,53 & 0,69 & 0,20 & 0,00 & 0,35 & 0,00 & 0,03 \\
\hline ADIB & 0,15 & 0,12 & 0,75 & 0,05 & 0,59 & 0,79 & 0,09 & 0,02 & 0,29 & 0,01 & 0,09 \\
\hline AUB & 0,11 & 0,07 & 0,87 & 0,02 & 0,66 & 0,75 & 0,03 & 0,04 & 0,30 & 0,01 & 0,13 \\
\hline BB & 0,14 & 0,12 & 0,85 & 0,08 & 0,67 & 0,79 & 0,02 & 0,02 & 0,30 & 0,01 & 0,04 \\
\hline KFH & 0,11 & $-0,03$ & 0,79 & 0,08 & 0,45 & 0,57 & 0,10 & 0,14 & 0,22 & 0,01 & 0,08 \\
\hline BAJ & 0,10 & 0,08 & 0,87 & 0,18 & 0,59 & 0,68 & 0,03 & 0,02 & 0,20 & 0,01 & 0,10 \\
\hline ARB & 0,14 & 0,12 & 0,84 & 0,15 & 0,64 & 0,77 & 0,02 & 0,01 & 0,18 & 0,03 & 0,22 \\
\hline SB & 0,16 & 0,15 & 0,82 & 0,27 & 0,52 & 0,64 & 0,02 & 0,01 & 0,18 & 0,02 & 0,14 \\
\hline BSF & 0,14 & 0,14 & 0,77 & 0,17 & 0,65 & 0,85 & 0,01 & 0,01 & 0,13 & 0,02 & 0,13 \\
\hline ATKB & 0,10 & 0,07 & 0,75 & 0,04 & 0,73 & 0,98 & 0,02 & 0,03 & 0,20 & 0,02 & 0,16 \\
\hline KTKB & 0,09 & 0,06 & 0,67 & 0,03 & 0,62 & 0,92 & 0,02 & 0,03 & 0,33 & 0,01 & 0,15 \\
\hline TFKB & 0,12 & 0,07 & 0,65 & 0,04 & 0,72 & 1,12 & 0,03 & 0,05 & 0,23 & 0,02 & 0,13 \\
\hline
\end{tabular}


Tablo 6: Bankaların Genel Karar Matrisi

\begin{tabular}{|c|c|c|c|c|c|c|c|c|c|c|c|}
\hline Genel & $\mathbf{1}$ & $\mathbf{2}$ & $\mathbf{3}$ & $\mathbf{4}$ & $\mathbf{5}$ & $\mathbf{6}$ & $\mathbf{7}$ & $\mathbf{8}$ & $\mathbf{9}$ & $\mathbf{1 0}$ & $\mathbf{1 1}$ \\
\hline BAJ & 0,118 & 0,099 & 0,843 & 0,241 & 0,601 & 0,713 & 0,015 & 0,019 & 0,130 & 0,011 & 0,100 \\
\hline ARB & 0,142 & 0,123 & 0,829 & 0,126 & 0,661 & 0,797 & 0,013 & 0,019 & 0,185 & 0,024 & 0,165 \\
\hline SB & 0,178 & 0,168 & 0,791 & 0,288 & 0,538 & 0,680 & 0,013 & 0,010 & 0,145 & 0,022 & 0,122 \\
\hline BSF & 0,153 & 0,148 & 0,785 & 0,173 & 0,650 & 0,829 & 0,018 & 0,005 & 0,151 & 0,017 & 0,111 \\
\hline CIMB & 0,058 & 0,055 & 0,899 & 0,137 & 0,709 & 0,789 & 0,010 & 0,004 & 0,205 & 0,008 & 0,135 \\
\hline AIBB & 0,070 & 0,070 & 0,840 & 0,123 & 0,658 & 0,802 & 0,020 & 0,001 & 0,305 & 0,005 & 0,077 \\
\hline PIBB & 0,072 & 0,067 & 0,901 & 0,177 & 0,706 & 0,784 & 0,007 & 0,005 & 0,196 & 0,009 & 0,122 \\
\hline BR & 0,153 & 0,135 & 0,790 & 0,271 & 0,673 & 0,851 & 0,022 & 0,018 & 0,139 & 0,019 & 0,128 \\
\hline DIB & 0,143 & 0,106 & 0,760 & 0,139 & 0,615 & 0,809 & 0,060 & 0,038 & 0,163 & 0,021 & 0,143 \\
\hline SIB & 0,170 & 0,139 & 0,666 & 0,095 & 0,553 & 0,833 & 0,063 & 0,031 & 0,223 & 0,014 & 0,085 \\
\hline EIB & 0,107 & 0,104 & 0,764 & 0,050 & 0,586 & 0,767 & 0,124 & 0,004 & 0,325 & 0,009 & 0,080 \\
\hline ADIB & 0,135 & 0,109 & 0,816 & 0,079 & 0,630 & 0,773 & 0,057 & 0,026 & 0,224 & 0,017 & 0,126 \\
\hline AUB & 0,112 & 0,086 & 0,872 & 0,046 & 0,698 & 0,800 & 0,023 & 0,025 & 0,274 & 0,013 & 0,114 \\
\hline BB & 0,118 & 0,082 & 0,870 & 0,060 & 0,703 & 0,808 & 0,012 & 0,036 & 0,266 & 0,010 & 0,088 \\
\hline KFH & 0,120 & 0,024 & 0,809 & 0,092 & 0,481 & 0,594 & 0,075 & 0,096 & 0,342 & 0,011 & 0,093 \\
\hline ATKB & 0,078 & 0,042 & 0,718 & 0,130 & 0,661 & 0,922 & 0,042 & 0,030 & 0,258 & 0,009 & 0,107 \\
\hline KTKB & 0,081 & 0,045 & 0,694 & 0,137 & 0,603 & 0,875 & 0,019 & 0,019 & 0,324 & 0,011 & 0,143 \\
\hline TFKB & 0,097 & 0,029 & 0,605 & 0,139 & 0,673 & 1,126 & 0,047 & 0,046 & 0,247 & 0,010 & 0,101 \\
\hline ASBB & 0,191 & 0,118 & 0,768 & 0,093 & 0,372 & 0,485 & 0,059 & 0,072 & 0,335 & 0,010 & 0,052 \\
\hline ABIB & 0,101 & 0,035 & 0,850 & 0,252 & 0,532 & 0,626 & 0,105 & 0,066 & 0,167 & $-0,001$ & $-0,010$ \\
\hline BISB & 0,097 & 0,008 & 0,753 & 0,158 & 0,587 & 1,511 & 0,171 & 0,089 & 0,158 & 0,002 & 0,010 \\
\hline
\end{tabular}

Ülkelerin sıralaması için oluşturulan karar matrislerine yönelik 2012 yılı örnek tablosu Tablo 7'de ülkelerin genel karar matrisi ise Tablo 8'de verilmiştir.

Tablo 7: 2012 Y1lı Ülkelerin Karar Matrisi

\begin{tabular}{|c|c|c|c|c|c|c|c|c|c|c|c|}
\hline ÜLKELER (2012) & $\mathbf{1}$ & $\mathbf{2}$ & $\mathbf{3}$ & $\mathbf{4}$ & $\mathbf{5}$ & $\mathbf{6}$ & $\mathbf{7}$ & $\mathbf{8}$ & $\mathbf{9}$ & $\mathbf{1 0}$ & $\mathbf{1 1}$ \\
\hline SUUDİ ARABİSTAN & 0,13 & 0,12 & 0,82 & 0,19 & 0,60 & 0,73 & 0,02 & 0,01 & 0,17 & 0,02 & 0,15 \\
\hline MALEZYA & 0,08 & 0,07 & 0,88 & 0,18 & 0,62 & 0,71 & 0,02 & 0,01 & 0,33 & 0,01 & 0,16 \\
\hline BAE & 0,14 & 0,11 & 0,73 & 0,08 & 0,57 & 0,79 & 0,12 & 0,03 & 0,27 & 0,01 & 0,08 \\
\hline KUVEYT & 0,12 & 0,05 & 0,84 & 0,06 & 0,59 & 0,71 & 0,05 & 0,07 & 0,28 & 0,01 & 0,08 \\
\hline TÜRKIYYE & 0,10 & 0,07 & 0,69 & 0,04 & 0,69 & 1,00 & 0,03 & 0,04 & 0,25 & 0,01 & 0,15 \\
\hline BAHREYN & 0,14 & 0,06 & 0,84 & 0,21 & 0,44 & 0,53 & 0,21 & 0,08 & 0,24 & $-0,01$ & $-0,18$ \\
\hline
\end{tabular}


Tablo 8: Ülkelerin Genel Karar Matrisi

\begin{tabular}{|c|c|c|c|c|c|c|c|c|c|c|c|}
\hline ÜLKELER (Genel) & $\mathbf{1}$ & $\mathbf{2}$ & $\mathbf{3}$ & $\mathbf{4}$ & $\mathbf{5}$ & $\mathbf{6}$ & $\mathbf{7}$ & $\mathbf{8}$ & $\mathbf{9}$ & $\mathbf{1 0}$ & $\mathbf{1 1}$ \\
\hline SUUDİ ARABİSTAN & 0,15 & 0,13 & 0,81 & 0,21 & 0,61 & 0,75 & 0,01 & 0,01 & 0,15 & 0,02 & 0,12 \\
\hline MALEZYA & 0,09 & 0,08 & 0,86 & 0,18 & 0,69 & 0,81 & 0,01 & 0,01 & 0,21 & 0,01 & 0,12 \\
\hline BAE & 0,14 & 0,11 & 0,75 & 0,09 & 0,60 & 0,80 & 0,08 & 0,02 & 0,23 & 0,02 & 0,11 \\
\hline KUVEYT & 0,12 & 0,06 & 0,85 & 0,07 & 0,63 & 0,73 & 0,04 & 0,05 & 0,29 & 0,01 & 0,10 \\
\hline TÜRKİY & 0,09 & 0,04 & 0,67 & 0,14 & 0,65 & 0,97 & 0,04 & 0,03 & 0,28 & 0,01 & 0,12 \\
\hline BAHREYN & 0,13 & 0,05 & 0,79 & 0,17 & 0,50 & 0,87 & 0,11 & 0,08 & 0,22 & 0,00 & 0,02 \\
\hline
\end{tabular}

Çalışmada yer alan bankalar için uygulanan TOPSIS yönteminin sonuçlarına göre bankalar sıralanmıştır. Tablo 5'te, 6 farklı ülkede faaliyette bulunan 21 bankanın 2012-2019 yıllarına ait finansal performans sıralamaları gösterilmiştir.

Tablo 9: 2012 -2019 Yılları Bankaların Performans Siralamaları

\begin{tabular}{|c|c|c|c|c|c|c|c|c|c|}
\hline Ülkeler & Bankalar & 2012 & 2013 & 2014 & 2015 & 2016 & 2017 & 2018 & 2019 \\
\hline \multirow{4}{*}{ Malezya } & CIMB & 15 & 12 & 12 & 13 & 11 & 10 & 9 & 9 \\
\hline & AIBB & 14 & 14 & 14 & 11 & 9 & 11 & 13 & 15 \\
\hline & PIBB & 5 & 7 & 13 & 16 & 13 & 12 & 14 & 13 \\
\hline & BR & 6 & 5 & 5 & 8 & 10 & 8 & 10 & 12 \\
\hline \multirow{3}{*}{ Bahreyn } & ASBB & 12 & 17 & 18 & 18 & 17 & 16 & 18 & 18 \\
\hline & ABIB & 20 & 20 & 21 & 21 & 21 & 21 & 21 & 21 \\
\hline & BISB & 21 & 21 & 20 & 20 & 20 & 20 & 20 & 4 \\
\hline \multirow{4}{*}{ BAE } & DIB & 17 & 13 & 10 & 6 & 7 & 5 & 4 & 10 \\
\hline & SIB & 1 & 2 & 4 & 14 & 14 & 13 & 11 & 14 \\
\hline & EIB & 18 & 18 & 17 & 15 & 15 & 14 & 6 & 5 \\
\hline & ADIB & 3 & 3 & 2 & 4 & 6 & 7 & 3 & 11 \\
\hline \multirow{3}{*}{ Kuveyt } & AUB & 8 & 4 & 6 & 5 & 5 & 3 & 2 & 2 \\
\hline & BB & 13 & 16 & 11 & 10 & 4 & 9 & 5 & 6 \\
\hline & KFH & 19 & 19 & 19 & 19 & 19 & 17 & 15 & 16 \\
\hline \multirow{4}{*}{$\begin{array}{l}\text { Suudi } \\
\text { A. }\end{array}$} & BAJ & 16 & 15 & 16 & 3 & 12 & 15 & 17 & 17 \\
\hline & ARB & 2 & 1 & 1 & 1 & 1 & 1 & 7 & 1 \\
\hline & SB & 9 & 11 & 7 & 9 & 3 & 4 & 1 & 8 \\
\hline & BSF & 4 & 10 & 3 & 2 & 2 & 2 & 8 & 3 \\
\hline \multirow{3}{*}{ Türkiye } & ATKB & 7 & 6 & 9 & 12 & 16 & 18 & 19 & 20 \\
\hline & КТКВ & 10 & 8 & 8 & 7 & 8 & 6 & 12 & 7 \\
\hline & TFKB & 11 & 9 & 15 & 17 & 18 & 19 & 16 & 19 \\
\hline
\end{tabular}


2012 yılına ait finansal performans sıralamasına göre en başarılı bankanın Birleşik Arap Emirlikleri ülkesinden Sharjah Islamic Bank olduğu tespit edilmiştir. Ülke bazında incelenecek olursa Malezya, Kuveyt ve Türkiye gibi ülkelerde faaliyet gösteren bankalar genelde orta sıralarda bulunmaktadır. Suudi Arabistan bankaları 2012 yılında başarılı bir finansal performans göstermiştir. Bahreyn'deki bankalar ise bu değerlendirmede genel itibariyle son sıralarda yer almaktadır. Türkiye' de 2012 yılı performans puanlarına göre en başarılı bankanın Albaraka Türk Katılım Bankası olduğu tespit edilmiştir.

2013 yılına ait finansal performans sıralamasına göre en başarılı banka Suudi Arabistan Al Rajhi Bank olmuştur. Ülke durumlarına bakılacak olursa Bahreyn'de faaliyet gösteren bankalar alt sıralarda yer alırken, Türkiye' deki bankalar genel olarak üst sıralarda yer almıştır. Malezya'daki ve Türkiye'deki bankaların bir önceki yıla göre finansal performansını artırdığını söylemek mümkündür. Kuveyt bankalarının da genel olarak finansal performansını düşürdüğü görülmektedir. Diğer ülkelerde katılım bankalarının sektörden aldıkları pay Türkiye'ye göre yüksek olmasına rağmen Türkiye'deki katılım bankaları 2013 yılında oldukça başarılı bir finansal performans göstermiştir.

2014 yılına ait finansal performans sıralamasına göre en başarılı bankanın Suudi Arabistan bankası Al Rajhi Bank olduğu tespit edilmiştir. Bahreyn'deki bankalar diğer yıllarda olduğu gibi 2014 yılında da son sıralarda yer almaktadır. Türkiye'deki bankaların ise bir önceki yıla göre finansal performansında düşüş söz konusudur.

2015 yılına ait finansal performans sıralamasına göre Suudi Arabistan bankası Al Rajhi Bank'ın en başarılı banka olduğu tespit edilmiştir. Bahreyn'de faaliyet gösteren bankalar 2015 yılında da son sıralarda yer almaktadır. Türkiye'deki katılım bankaları önceki yıllara göre finansal performansını düşürmüştür. Malezya bankaları, Affin Islamic Bank Berhad (AIBB) hariç finansal performansını genel olarak düşürmüştür. Türkiye' deki bankalar içerisinde 7. Sırada bulunan banka Kuveyt Türk Katılım Bankası'nın 2015 yılında en başarılı banka olduğu görülmektedir.

2016 yılına ait finansal performans sıralamasına göre en başarılı banka Suudi Arabistan'da faaliyet gösteren Al Rajhi Bank olmuştur. Bank Al Jazira ise 2015 yılında 3. sırada yer alırken 2016 yılında 12. sıraya gerilemiştir. Malezya'daki bankalar 2016 yılında önceki yıla göre finansal performanslarını artırmıştır. Kuveyt İslami bankaları 2016 yılında finansal performanslarını artırmıştır. Türkiye'deki katılım bankalarının 2016 yılında da gerileme trendinde olduğu görülmektedir. 2016 yılında Türkiye'deki katılım bankaları arasında en başarılı banka Kuveyt Türk Katılım bankası olmuştur.

2017 yılına ait finansal performans sıralamasına göre en başarılı banka Suudi Arabistan Bankası Al Rajhi Bank olmuştur. Bahreyn İslami bankaları yine son sıralarda yer alırken BAE'de faaliyet gösteren bankalar finansal performanslarını oldukça düşürmüştür. Türkiye'deki katılım bankaları ise Kuveyt Türk Katılım Bankası hariç finansal performanslarını önceki yıllara göre düşürmeye devam etmiştir. 
2018 yılına ait finansal performans sıralamasına göre Suudi Arabistan Samba Bank en başarılı banka olmuştur. Samba Bank dışında diğer Suudi Arabistan bankalarında gerileme yaşandığı görülmektedir. Türkiye' deki katılım bankaları 19., 12. ve 16. sıralarda yer alarak 2018 yılında oldukça düşük bir finansal performans sergilemiştir. Kuveyt bankaları ise genel olarak finansal performans başarısını yükseltmiştir.

2019 yılına ait finansal performans sıralamasına göre Suudi Arabistan Al Rajhi Bankası en başarılı performans gösteren banka olmuştur. Bahreyn bankaları genel olarak sıralamada önceki yıllara yakın sıralamalarda yer alırken Bahrain Islamic Bank gelişme göstererek 4. sıraya yükselmiştir. Türkiye' deki katılım bankaları ise 2019 yılında da başarılı bir performans sergileyemediği tespit edilmiştir. Ancak Kuveyt Türk Katılım Bankası 7. sırada yer alarak nispeten daha başarılı bir finansal performans sergilemiştir.

\section{Katılım Bankalarının Genel Finansal Performans Değerlendirmesi Sonuçları}

21 adet katılım bankasının $\mathrm{Ci}^{*}$ değerleri baz alınarak TOPSIS yöntemi uygulanmıştır. Uygulamada 2012-2019 yıllarına ait tüm $\mathrm{Ci}^{*}$ değerleri ile yeniden performans siralaması oluşturulmuştur. Bu uygulamanın sonuçlarına aşağıda yer verilmiştir.

Tablo 10: Genel Performans Değerlendirmesi ve Sıralaması

\begin{tabular}{|c|c|c|c|}
\hline Ülkeler & Aday & $\mathrm{Ci}^{*}$ & Siralamasi \\
\hline \multirow{4}{*}{ Suudi A. } & BAJ & 0,608345 & 14 \\
\hline & ARB & 0,756374 & 1 \\
\hline & SB & 0,676103 & 5 \\
\hline & BSF & 0,720294 & 2 \\
\hline \multirow{4}{*}{ Malezya } & CIMB & 0,630455 & 12 \\
\hline & AIBB & 0,618393 & 13 \\
\hline & PIBB & 0,632299 & 11 \\
\hline & BR & 0,666596 & 6 \\
\hline \multirow{4}{*}{ BAE } & BRIB & 0,645508 & 8 \\
\hline & SIB & 0,64785 & 7 \\
\hline & EIB & 0,558198 & 16 \\
\hline & ADIB & 0,677804 & 4 \\
\hline \multirow{3}{*}{ Kuveyt } & AUB & 0,683808 & 3 \\
\hline & BB & 0,645198 & 9 \\
\hline & $\mathrm{KFH}$ & 0,433189 & 19 \\
\hline \multirow{3}{*}{ Türkiye } & ATKB & 0,572852 & 15 \\
\hline & KTKB & 0,641481 & 10 \\
\hline & TFKB & 0,545412 & 17 \\
\hline \multirow{3}{*}{ Bahreyn } & ASBB & 0,520161 & 18 \\
\hline & ABIB & 0,261981 & 20 \\
\hline & BISB & 0,260499 & 21 \\
\hline
\end{tabular}


Bankaların 8 yıllık verileri ile oluşan genel finansal performans sıralamalarına göre ilk üç sırada yer alan bankalar sırasıyla Suudi Arabistan bankaları ARB, BSF ve Kuveyt bankası AUB'dir. Suudi Arabistan bankaları genel performans sıralamasında BAJ bankası hariç ilk beş sırada yer almaktadırlar. BAJ bankası ise oldukça düşük bir finansal performans sergileyerek 14. Sırada yer almıştır. Malezya bankaları BR bankası hariç genel finansal performans sıralamasında orta kısımlarda yer almışlardır. BR bankası ise 6. Sırada yer alarak nispeten yüksek bir finansal performans göstermektedir. BAE bankaları genel finansal performans sıralamasında ortanın üstünde yer alarak iyi bir finansal performans sergilemektedirler. Kuveyt bankalarından AUB bankası 3. Sırada yer alarak diğer Kuveyt bankalarında oldukça yüksek bir finansal performans sergilerken BB bankası 9. Sırada yer almakta, KFH bankası ise 19 sırada yer almaktadır. Türkiye bankalarında KTKB bankası ülkedeki diğer bankalardan daha başarılı bir finansal performansa sahiptir. Ancak ATKB ve TFKB bankaları ortanın altında yer alan sıralamaları ile düşük bir finansal performans ortaya koymaktadır. Bahreyn bankaları ise genel finansal performans sıralamasında son sıralarda yer almaktadırlar.

Ülkelerin $C_{i}^{*}$ değerleri ve sıralamalarına yönelik sonuçlar aşağıdaki tablolarda verilmiştir.

Tablo 11: Ülkelerin TOPSIS Sonucuna Yönelik CI* Değerleri

\begin{tabular}{|c|l|l|l|l|l|l|l|l|}
\hline ÜLKELER /Ci* Değerleri & $\mathbf{2 0 1 2}$ & $\mathbf{2 0 1 3}$ & $\mathbf{2 0 1 4}$ & $\mathbf{2 0 1 5}$ & $\mathbf{2 0 1 6}$ & $\mathbf{2 0 1 7}$ & $\mathbf{2 0 1 8}$ & $\mathbf{2 0 1 9}$ \\
\hline SUUDİ ARABİSTAN & 0,76 & 0,67 & 0,67 & 0,69 & 0,73 & 0,70 & 0,70 & 0,59 \\
\hline MALEZYA & 0,74 & 0,68 & 0,65 & 0,60 & 0,62 & 0,61 & 0,65 & 0,54 \\
\hline BAE & 0,69 & 0,61 & 0,63 & 0,60 & 0,60 & 0,58 & 0,71 & 0,57 \\
\hline KUVEYT & 0,62 & 0,51 & 0,48 & 0,49 & 0,55 & 0,57 & 0,68 & 0,57 \\
\hline TÜRKIYYE & 0,78 & 0,71 & 0,64 & 0,52 & 0,46 & 0,43 & 0,49 & 0,43 \\
\hline BAHREYN & 0,12 & 0,21 & 0,17 & 0,18 & 0,18 & 0,17 & 0,28 & 0,40 \\
\hline
\end{tabular}

Tablo 12: Ülkelerin TOPSIS Sonucuna Yönelik Sıralamaları

\begin{tabular}{|c|c|c|c|c|c|c|c|c|}
\hline ÜLKELER / SIRALAMALAR & $\mathbf{2 0 1 2}$ & $\mathbf{2 0 1 3}$ & $\mathbf{2 0 1 4}$ & $\mathbf{2 0 1 5}$ & $\mathbf{2 0 1 6}$ & $\mathbf{2 0 1 7}$ & $\mathbf{2 0 1 8}$ & $\mathbf{2 0 1 9}$ \\
\hline SUUDİ ARABİSTAN & 2 & 3 & $\mathbf{1}$ & $\mathbf{1}$ & $\mathbf{1}$ & $\mathbf{1}$ & 2 & $\mathbf{1}$ \\
\hline MALEZYA & 3 & 2 & 2 & 2 & 2 & 2 & 4 & 4 \\
\hline BAE & 4 & 4 & 4 & 3 & 3 & 3 & $\mathbf{1}$ & 2 \\
\hline KUVEYT & 5 & 5 & 5 & 5 & 4 & 4 & 3 & 3 \\
\hline TÜRKIYE & $\mathbf{1}$ & $\mathbf{1}$ & 3 & 4 & 5 & 5 & 5 & 5 \\
\hline BAHREYN & 6 & 6 & 6 & 6 & 6 & 6 & 6 & 6 \\
\hline
\end{tabular}


Ülkelerin finansal performans sıralamalarına göre 2012 yılında Türkiye 1. Sırada yer alırken Suudi Arabistan 2 sirada, Malezya ise 3. Sirada yer almaktadır. 2013 yılında da yine aynı sıralamalar söz konusudur. 2014 yılında Türkiye'nin 1. Sırada ki yerini Suudi Arabistan'ın aldığı Malezya'nın 2. Sıraya yükseldiği, Türkiye'nin ise 3. Sırada kaldığı görülmektedir. 2015 yılında Suudi Arabistan 1. Sirada, Malezya 2. Siradayken BAE’nin 3. Siraya yükseldiği görülmektedir. 2016 ve 2017 yıllarında Suudi Arabistan, Malezya, BAE sıralaması 2015 yılı ile aynı kalmıştır. 2018 yılında BAE 1. Sıraya yükselirken, Suudi Arabistan 2. Sıraya, Malezya ise 4. Sıraya gerilemiş, Kuveyt ise 3. Sıraya yükselmiştir. 2019 yılında Suudi Arabistan 1. Sırada, BAE 2. Sırada, Kuveyt 3. Sırada yer almıştır. Türkiye ilk iki yıl çok iyi bir finansal performans sergilerken sonraki yıllarda performansı düşmüş ve 5. Sıraya kadar gerilemiştir. Malezya 2018 yılına kadar ilk üç sırada yer alırken 2018 ve 2019 yıllarında 4. Sıraya kadar gerilemiştir. Bahreyn ise tüm yıllarda 6. Sıradaki yerini korumuştur.

Tablo 13: Ülkelerin İslami Bankacılık Aktif Toplamları Sıralaması (2012-2019)

\begin{tabular}{|c|c|c|c|c|c|c|c|c|}
\hline ÜLKELER / SIRALAMALAR & $\mathbf{2 0 1 2}$ & $\mathbf{2 0 1 3}$ & $\mathbf{2 0 1 4}$ & $\mathbf{2 0 1 5}$ & $\mathbf{2 0 1 6}$ & $\mathbf{2 0 1 7}$ & $\mathbf{2 0 1 8}$ & $\mathbf{2 0 1 9}$ \\
\hline SUUDİ ARABISTAN & $\mathbf{1}$ & $\mathbf{1}$ & $\mathbf{1}$ & $\mathbf{1}$ & $\mathbf{1}$ & $\mathbf{1}$ & $\mathbf{1}$ & $\mathbf{1}$ \\
\hline MALEZYA & 2 & 2 & 2 & 3 & 2 & 2 & 2 & 2 \\
\hline BAE & 3 & 3 & 3 & 2 & 3 & 3 & 3 & 3 \\
\hline KUVEYT & 4 & 4 & 4 & 4 & 4 & 4 & 4 & 4 \\
\hline TÜRKIYY & 6 & 6 & 5 & 5 & 5 & 5 & 5 & 6 \\
\hline BAHREYN & 5 & 5 & 6 & 6 & 6 & 6 & 6 & 5 \\
\hline
\end{tabular}

Ülkelerin toplam aktif sıralamalarına göre tüm yıllarda Suudi Arabistan, Malezya, BAE ve Kuveyt ilk dört sıradaki yerini korumaktadır. Dolayısıyla bu ülkeler küresel İslami bankacılık toplam aktif payı en yüksek ülkeler arasındadır. Türkiye ve Bahreyn'in ise kendi arasında yer değiştirdiği görülmektedir. 2014-2018 yıllarında Türkiye'nin toplam aktifi Bahreyn'e göre daha yüksektir. 2012, 2013 ve 2019 yıllarında ise Bahreyn'in toplam aktifi Türkiye'den daha fazla olduğu tespit edilmiştir. Tablo 13'ü oluştururken yararlanılan veriler Ekler bölümünde yer almaktadir.

Türkiye, Tablo 12'de 2012 ve 2013 yıllarında finansal performans olarak birinci sırada yer alırken aktif toplam sıralamasında ise altıncı sırada yer almıştır. Bu önemli fark için Türkiye'deki katılım bankalarının aktif toplamları düşük olsa da iyi bir finansal yönetim sağlayarak başarılı bir sonuç sergilediği söylenebilmektedir. Aktif toplamlarının düşük olmasının bu dönemlerde banka sayısının az olması, ürün çeşitlendirmesinin daha az olması ve katılım bankacılığının daha az yaygın olması gibi nedenlerden kaynaklandığı düşünülmektedir. 2016-2019 yıllarında ise finansal performans sıralaması ile toplam aktif 
sıralaması birbirine paralellik oluşturmaktadır. Diğer ülkelerde ise genel olarak bir paralellik söz konusu olmuştur.

Ülkelerin genel finansal performans sıralaması ve toplam aktif payları aşağıdaki tabloda yer almaktadır.

Tablo 14: Ülkelerin TOPSIS Sıralamaları İle Toplam Aktif Payları Karşılaştırması

\begin{tabular}{|c|c|c|c|c|c|}
\hline ÜLKELER & $\mathrm{Si}^{+}$ & $\mathrm{Si}^{-}$ & $\mathrm{Ci}^{*}$ & $\begin{array}{c}\text { ÜLKELERIN ISLAMI BANKACILIK } \\
\text { AKTIF TOPLAMLARI ORTALAMASI } \\
\mathbf{( 2 0 1 2 - 2 0 1 9 )}\end{array}$ & $\begin{array}{c}\text { TOPSIS } \\
\text { SIRALAMASI }\end{array}$ \\
\hline $\begin{array}{c}\text { SUUDI } \\
\text { ARABISTAN }\end{array}$ & 0,04 & 0,11 & 0,72 & $\% 40$ & $\mathbf{1}$ \\
\hline MALEZYA & 0,05 & 0,10 & 0,67 & $\% 21$ & 3 \\
\hline BAE & 0,05 & 0,09 & 0,65 & $\% 18$ & 4 \\
\hline KUVEYT & 0,06 & 0,08 & 0,57 & $\% 11$ & 5 \\
\hline TÜRKIYY & 0,06 & 0,08 & 0,57 & $\% 5$ & 6 \\
\hline BAHREYN & 0,11 & 0,02 & 0,16 & $\% 5$ & 2 \\
\hline
\end{tabular}

Ülkelerin genel performans sıralamalarına göre en başarılı ilk üç ülke sırasıyla Suudi Arabistan, Malezya ve BAE'dir. Kuveyt bu genel sıralamada dördüncü sırada yer alırken Türkiye beşinci sırada ve Bahreyn ise altıncı sırada yer almaktadır. Çalışmanın temel amaçları arasında yer alan küresel İslami bankacılık toplam aktif sıralaması ile finansal performans sonuçlarının karşılaştırılması konusuna bakılacak olursa her iki sıralama da birebir örtüşmektedir.

\section{Sonuç}

Bankacılık sektörü, finansal sistem içerisinde her geçen gün önemi artan ve sürekli büyüyen bir sektördür. Bu sektör içerisinde yer alan İslami Bankacılık da son yıllarda varlıklarını artırmakta ve mevcut sektörde büyümeye devam etmektedir. Ortadoğu ve Kuzeydoğu Asya bölgelerinde yer alan ülkelerin yanı sıra Avrupa ülkeleri, $A B D$ ve diğer ülkelerde de faaliyet alanı bulmaktadır. Türkiye'de de bu sistem katılım bankacılığı olarak isimlendirilmekte ve gelişimi desteklenmektedir. TKBB'nin 2023 hedefleri arasında katılım bankacılığı sisteminin Türkiye' deki bankacılık sektöründen \%15 pay alması yer almaktadır. Bu hedef doğrultusunda 2015 yılında Vakıf Katılım, 2016 yılında Ziraat Katılım ve 2019 yılında Emlak Katılım bankaları sisteme dâhil edilerek mevcut pay artırılmaya çalışılmaktadır.

Bu çalışmada 6 ülkede faaliyet gösteren 21 adet katılım bankasının veya İslami bankanın finansal performansları TOPSIS yöntemi kullanılarak değerlendirilmiştir. Ayrıca bankaların ortalamaları hesaplanarak ülkeler için bir finansal performans sıralaması oluşturulmuştur. Değerlendirmeye dâhil edilen ülkeler; Suudi Arabistan, BAE, Kuveyt, Malezya, Bahreyn ve Türkiye'dir. Bu çalışmada yer alan ülkeler seçilirken IFDI 2019 raporunun İslami bankacılık 
toplam aktif payları sıralaması dikkate alınmıştır. Bu sıralamaya göre İslami Bankalar arasında en büyük toplam aktif payına sahip olan ülke Suudi Arabistan, en düşük toplam aktif payına sahip olan ülke ise Bahreyn'dir. Bu çalışmanın sonucunda en yüksek finansal başarı sağlayan bankalar Suudi Arabistan' da faaliyet gösteren bankalar, en düşük başarı sağlayan bankalar ise Bahreyn'de faaliyet gösteren bankalardır. Türkiye ise İslami bankacılık toplam aktifleri sıralamasında 7. sırada bulunmaktadır. Bu çalışmanın sonucuna göre İslami bankacılık toplam aktif büyüklükleri ile İslami bankaların finansal performans başarısı birbirine paralellik oluşturmaktadır. Türkiye'nin finansal performans başarısında katılım bankalarının aktif büyüklerinin yüksek olması, bu aktiflerin doğru bir şekilde ürün çeşitlendirmesinin yapılması ve yönetim politikaları önem arz etmektedir.

Türkiye'deki bankaların finansal performans başarısına ayrıntılı olarak bakacak olursak en başarılı performans gösterdiği dönem 2013 yılı olarak tespit edilmiştir. Bu durumun nedeni olarak 2012 yılında sukuk ihraçları çerçevesinde atılan önemli adımların olumlu yansımaları olarak değerlendirilmektedir. Türkiye'deki bankalardan Kuveyt Türk Katılım Bankası genel sıralamada 10. sırada yer alarak nispeten yüksek bir finansal performans başarısı yakalamıştır. Kuveyt Türk Katılım Bankası Türkiye'deki katılım bankaları arasında en yüksek aktif büyüklüğüne sahiptir. Ayrıca GFMAG (Global Finance Magazine) 2019 verilerine göre de Türkiye'nin en başarılı katılım bankası olarak Kuveyt Türk Katılım Bankası seçilmiştir.

Katılım bankacılığı sistemi fon toplayabildiği ve bu fonları iyi yönetebildiği kadar finansal performansını artırmaktadır. Türkiye'de Emlak Katılım bankasının devlet desteği ile sektöre yeni giriş yapmış olması sektörü güçlendirmek adına önemli bir hamledir. Katılım bankalarının sayısının artırılması, şube sayısının artırılması ve İslami finans ürünlerinin çeşitlendirilmesi toplanan fon miktarını artırabilecektir. Katılım bankalarının yüksek miktarlarda fon toplayabilmesi ve bu fonların stratejik yatırım sahalarında değerlendirilmesi sektörün büyümesine ve bankaların daha başarılı performans sergileyerek dünyada önemli bir yer edinmesine yardımcı olabilecektir.

TKBB 2023 hedefleri doğrultusunda katılım bankalarının Türkiye'de bankacılık sektöründen almış olduğu payları \%15 hedefine çıkarmak istemektedir. Bu hedef ile bankaların performansları değerlendirildiğinde bankaların Kuveyt Türk hariç 2012-2019 yılları arasında sürekli gerileyen bir performansa sahip olması bu hedefin gerçekleştirilmesi açısından engel teşkil eden durumlardan biri olduğu görülmektedir. Bu hedef doğrultusunda bu bankaların performanslarını artırmak için önemli adımlar atmaları gerekmektedir. Katılım bankalarının finansal performans sıralamaları ve dünya İslami bankacılık aktif toplamları sıralaması değerlendirildiğinde her iki sıralamanın paralellik gösterdiği anlaşılmaktadır. Dolayısıyla bankaların finansal performanslarını daha başarılı hale getirmek istemeleri durumunda daha çok fon toplayıp daha fazla fon kullandırarak etkili bir yönetim politikası ile ve en önemlisi İslami finans ürünlerinde çeşitlendirmeye giderek daha başarılı olabilmeleri mümkün görünmektedir. Tabii tüm bu düşüncelerin yanı sıra performans sıralamasında önde gelen ülkelerden Malezya ve Türkiye hariç diğer ülkelerin petrol anlamında zengin olması ve bu petrolden sağlamış oldukları gelirleri İslami bankacılık sektörüne aktarmaları sayesinde 
pazara hâkim olmalarının göz ardı edilmemesi gerekmektedir. Malezya'nın ise bu sektörde başarılı performans sergilemesini ülke olarak İslami finans konusunda önemli yatırımlar yapmaları ve bu sektöre vermiş oldukları değerle yakından ilişkili olduğu düşünülmektedir. Ayrıca ürün çeşitlendirme konusunda kendini geliştirmiş olan Malezya diğer zengin ülkelerin arasında yükselen bir değere sahip olmaktadır.

Tanıtım konusunda katılım bankaları için gerekli çalışmaların yapılması ve İslami finans ürünlerinin çeşitlendirilmesi Türkiye'deki sektörün güçlenmesini sağlayabilecek yapı taşları olabileceği düşünülmektedir. Katılım bankalarının yüksek miktarlarda fon toplayabilmesi ve bu fonların stratejik yatırım sahalarında değerlendirilmesi hem ülkenin ekonomik olarak güçlenmesine hem de bankaların daha başarılı performans sergileyerek dünyada önemli bir yer edinmesine yardımcı olabilecektir. Ayrıca katılım bankalarının şube sayılarının artırılması ve sektöre daha fazla bankanın giriş yapması da katılım bankacılığı sektörünün daha fazla fon toplayıp daha fazla kredi kullandırmasına olanak sağlayabilecektir. Bu fonların doğru yatırımlarda kullanılması sektörün büyümesine ve aynı zamanda ekonomiye de katkı sağlayabilecektir.

$\mathrm{Bu}$ çalışmada İslami bankacılık toplam aktifleri ile finansal performans sıralamalarının birbirini desteklediği tespit edilmiş ve bankaların veya ülkelerin aktif toplamlarını artırmaları finansal performanslarını da artırmalarını sağlayacak önemli bir etken olduğu sonucuna ulaşılmıştır. Alsu vd.(2018) çalışmalarında benzer ülkelere ve kısmen benzer finansal oranlar ile TOPSIS yöntemini kullanarak finansal performans karşılaştırması yapmışlar ve Türkiye' de faaliyet gösteren bankaların orta kısımlarda yer aldığı sonucuna ulaşmışlardır. Bu çalışmada ise finansal oranlar, bankalar ve ülkeler farklılaştırılarak TOPSIS uygulaması yapılmış ve çalışmanın devamında bankaların ortalaması alınarak ülkeler için sıralama oluşturulmuştur. Böylece daha önce herhangi bir çalışmada rastlanmamış bir karşılaştırma yapılarak literatüre katkı sağlanmaya çalışılmıştır. 


\section{Kaynakça}

Alrifai, T. (2017). İslami Finans ve Yeni Finansal Sistem. (Çev. Barış Satılmış) Ankara: Buzdağı Yayınevi

Alsu, E., Taşdemir, A., ve Kallo, Z. (2018). "Katılım Bankalarının Performanslarının Değerlendirilmesi: TOPSIS Yöntemi ile Uluslararası Karşılaştırma". Gaziantep University Journal of Social Sciences, 17(1), 303-316.

Arıçelik, G. (2010). “Ticari Bankalarda Performans Ölçümü: Camels Analizine Dayalı Bir İnceleme”’. Dokuz Eylül Üniversitesi, Yayınlanmış Yüksek Lisans Tezi.

Canbaz, M. (2018). Katılım Bankacılığı. İstanbul: Beta Basım Yayım Dağıtım A.Ş.

Coşkun, Ali. (2005). " İşletmelerde Performans Yönetimi: Bir Yönetim Muhasebesi Aracı Olarak Performans Karnesi"'. İstanbul Üniversitesi, Yayınlanmış Doktora Tezi.

Çelik, S., ve Doğan, İ. (2017). "Katılım Bankacılığının Doğuşu ve Tarihsel Gelişimi". F. Kaya içinde, Katılım Bankacılığı (15-45). İstanbul: Beta Basım Yayım Dağıtım A.Ş.

Dikkaya, M., ve Kutval, Y. (2014). Katılım Bankacılığı Türkiye Örneği. Ankara: Savaş Yayınevi.

Dymova, L., Sevastjanov, P., ve Tikhonenko, A. (2013). "An approach to generalization of fuzzy TOPSIS method". Information Sciences, 149-162.

Erdem, M., ve Tatlı, H. (2020). Teorik ve Pratik Bakımdan Dünya'da ve Türkiye'de İslami Finans. Ankara: Gazi Kitabevi.

ERNST \& YOUNG. (2016). World Islamic Banking Competitivenes Report. Erişim Tarihi: 22.10.2021.

ERNST \& YOUNG. (2017). Banking in Emerging Markets. GCC FinTech Play 2017. Erişim Tarihi: 22.10.2021.

Esmer, Y., \& BAĞCI, H. (2016). Katılım bankalarında finansal performans analizi: Türkiye örneği-Financial Performance Analysis of Participation Banks: The Case of Turkey. Mehmet Akif Ersoy Üniversitesi Sosyal Bilimler Enstitüsü Dergisi, 8(15), 17-30.

GFMAG. World's Best Islamic Financial Institutions 2020: Fair Winds Before The Storm. https://www.gfmag.com/magazine/may-2020/worlds-best-islamic-financialinstitutions-2020 adresinden alındı.Erişim Tarihi: 12.05.2020.

Ghasempour, S., ve Salamı, M. (2016). 'Ranking Iranian Private Banks Based on the CAMELS Model Using the AHP Hybrid Approach and TOPSIS". International Journal of Academic Research in Accounting, Finance and Management Sciences, 6(4), 52-62.

Güngör, K. (2015). "Malezya'daki Faizsiz Bankacılık Modelinin Türkiye'de Uygulanabilirliği Üzerine Bir Analiz". Göller Bölgesi Aylık Hakemli Ekonomi ve Kültür Dergisi Ayrıntl, 3(29), 54-61. 
IFDI. (2019). Islamic Finance Development Report 2012-2019. ICD-REFINITIV. Erişim Tarihi: 20.10.2021.

IFSB (Islamic Financial Services Board). Research - Reports - Proceedings - Metadata - Data by Country (Islamic Banking). https://www.ifsb.org adresinden alınd1. Erişim Tarihi: 24.10.2021.

IFSI. (2019). Islamic Financial Services Industry Stabıltty Report. Kuala Lumpur: Islamic Financial Services Board. Erişim Tarihi: 10.06.2020.

Kamaruddin, B. H., ve Mohd, R. (2013). "CAMEL Analysis of Islamic Banking and Conventional Banking in Malaysia". Business and Management Quarterly Review, 4(3 ve 4), 81-89.

Keleş, H. (2001). "Osmanlılarda 19. Yüzyıldaki Para Vakıflarının İşleyiş Tarzı ve İktisadi Sonuçları Üzerine Bir Tartışma". G.ü. Gazi Eğitim Fakültesi Dergisi, 21(1), 189-207.

Özer, M. A. (2009). Performans Yönetimi Uygulamalarında Performansın Ölçümü ve Değerlendirilmesi. Sayıştay Dergisi, (73), 3-29.

Özbek, A. (2017). Çok Kriterli Karar Verme Yöntemleri ve Excel İle Problem Çözümü. Ankara: Seçkin Yayıncılık.

Saldanlı, A., ve Sırma, İ. (2014). "TOPSIS Yönteminin Finansal Performans Göstergesi Olarak Kullanılabilirliği". Maramara Üniversitesi Öneri Dergisi, 11(41), 185-202.

Semiz, Y. (2016). "Osmanlı Devleti'nde Para Vakıfları". Selçuk Üniversitesi Sosyal Bilimler MYO Dergisi, 19(1), 89-101.

SERPAM. (2013). İslami Finans Kavramı, Ürünler, Dünya'da ve Türkiye'de Gelişimi ve Geleceği. İstanbul: Sermaye Piyasaları Araştırma ve Uygulama Merkezi.

Sufian, F., ve Noor, M. (2009). "The determinants of Islamic banks' efficiency changes". International Journal of Islamic and Middle Eastern Finance and Management, 2(2), 120-138.

Şahin, A., ve Tetik, N. (2020). “Katılım Bankalarının Finansal Performans Analizi”. Atatürk Üniversitesi İktisadi ve İdari Bilimler Dergisi, 34(2), 293-314.

TKKB (2020). Katılım Bankaları 2019, https://tkbb.org.tr/Documents/Yonetmelikler/KatilimBankalari-2019.pdf adresinden alındı.

Wanke, P., Azad, M. K., ve Barros, C. (2016). "Predicting efficiency in Malaysian Islamic banks: A two-stage TOPSIS and neural networks approach". Research in International Business and Finance, cilt: $36,485-498$.

Wanke, P., Hassan, M., ve Gavião, L. (2017). "Islamic Banking and Performance in The Asean Banking Industry: A TOPSIS Approach With Probabilistic Weights". International Journal of Business and Society, 18(1), 129-150. 
Yayar, R., ve Baykara, H. V. (2012). "TOPSIS Yöntemi İle Katılım Bankalarının Etkinliği ve Verimliliği Üzerine Bir Uygulama". Business and Economics Research Journal, 3(4), 21-42.

Yetiz, F. (2021). “TOPSIS Yöntemi İle Türk Katılım Bankalarının Performans Analizi ve Bankacılıkta Risk Yönetim Politikalarının Önemi". Journal of Empirical Economics and Social Sciences, 3(1), 121-138. 


\section{Extended Abstract}

Institutions classified as Islamic banks in the world literature and participation banks in Turkey differ from traditional banking and constitute a banking system that operates with interest-free instruments. Participation banks, which started operating in European countries, the United States and the Far East in recent years, continue to increase their popularity.

Participation banking has been developing around the world based on two basic models. The first of these is the conservative model implemented by the Gulf countries while the other is the model implemented by Malaysia. Malaysia develops and implements tools that are suitable for Islamic finance as alternatives to all other financial tools used in commercial banking. On the other hand, all banks in Iran operate in the Islamic banking sector.

Iran, Saudi Arabia, UAE, Kuwait, Qatar and Malaysia are among the leading countries in the global Islamic banking sector. Countries such as Indonesia, Bahrain, Turkey and Bangladesh are also in the top ten in the Islamic banking total assets ranking. The highest Islamic banking assets belong to Iran with 588 billion dollars and a share of $28.6 \%$. Additionally, the country with the highest number of Islamic banks is also Iran with 42 banks. The countries following Iran are: Saudi Arabia (24.9\%), Malaysia (11.1\%), UAE (8.7\%), Kuwait (6.3\%), Qatar (6.1\%), Turkey (2.6\%), Bangladesh (2.1\%) Indonesia (2.0\%) and Bahrain (1.8\%), respectively. Based on this, it can be said that Turkey is in a better position compared to countries such as Bangladesh, Bahrain and Indonesia in terms of Islamic banking assets. Countries such as Kuwait and Qatar, on the other hand, possess significant total assets despite having a low number of Islamic banks.

In terms of the share within countries' own banking sectors, Saudi Arabia is the country that has the highest share with $50-60 \%$. Kuwait ranks second with a share of $40.6 \%$. The share of interest-free banks within the banking sector in Turkey, which ranks last in this aspect, was $5.3 \%$ in 2018, while this share increased to 6.3\% in 2019. Participation Banks Association Of Turkey (TKBB) aims for the participation banking system to have a share of $15 \%$ within the banking sector in Turkey by 2023. In line with this goal, attempts are being made to increase the current share as Vakıf Participation was included in the system in 2015, Ziraat Participation in 2016 and Emlak Participation in 2019.

In the present study, the Technique for Order of Preference by Similarity to Ideal Solution (TOPSIS) method was used in the evaluation of participation banks' financial performance. The TOPSIS method was used in many studies in the literature, and was also used in the comparison of the financial performance of companies. In the TOPSIS method, the option closest to the ideal solution constitutes the best decision. In the present study, Capital Adequacy, Balance Structure, Asset Quality, Liquidity and Profitability ratios were used in the comparison of the international financial performances of participation banks. These ratios constitute the criteria of the application of the TOPSIS method. 8 years of financial data and 11 different financial ratios for 21 participation banks were used. The data of the Islamic banks operating in the countries included within the present study were accessed through the year- 
end activity reports published by each bank. The data for the participation banks in Turkey were accessed through TKBB. In the measurement of the banks selected for the study, data for the years 2012-2019 were used. The financial ratios used in the study were weighted equally, the banks that have been successful throughout the years were selected among the alternatives, and all alternatives were ranked. In the last step of the study, a TOPSIS application was carried out for all years. The countries included in the evaluation are: Saudi Arabia, UAE, Kuwait, Malaysia, Bahrain and Turkey. The Islamic banking asset share ranking in the 2012-2019 report published by the IFDI was taken into consideration in the selection of the countries included in the present study.

According to this ranking, the country with the largest asset share among Islamic banks is Saudi Arabia while the country with the lowest asset share is Bahrain. As a result of the present study, it was determined that the banks with the highest financial success are those operating in Saudi Arabia while the ones with the lowest success are those in Bahrain. Turkey is ranked seventh in the Islamic banking assets ranking. According to the results of the present study, the financial performance of the banks are consistent with the Islamic banking asset shares ranking. Therefore, it was determined that the financial success of participation banks is in parallel with Islamic banking asset sizes.

The participation banking system improves its financial performance as much as it can collect funds and manage these funds efficiently. The amount of funds collected can be increased by increasing the number of participation banks, increasing the number of branches and diversifying Islamic finance products. Enabling participation banks to collect large amounts of funds and utilize these funds in strategic investment areas can help improve the performance of banks and gain global importance.

As a result of the present study, it was determined that the most successful banks are those operating in countries such as Saudi Arabia, UAE and Kuwait. Al Rajhi Bank from Saudi Arabia, Ahli United Bank from Kuwait, Abu Dhabi Bank from the United Arab Emirates and Kuveyt Türk Participation Bank from Turkey were found to have demonstrated significant performance and were ranked in the top six. 


\section{EKLER}

Tablo 15: 2013 Y1lı Karar Matrisi

\begin{tabular}{|c|c|c|c|c|c|c|c|c|c|c|c|}
\hline 2013 & $\mathbf{1}$ & $\mathbf{2}$ & $\mathbf{3}$ & $\mathbf{4}$ & $\mathbf{5}$ & $\mathbf{6}$ & $\mathbf{7}$ & $\mathbf{8}$ & $\mathbf{9}$ & $\mathbf{1 0}$ & $\mathbf{1 1}$ \\
\hline CIMB & 0,054 & 0,050 & 0,911 & 0,107 & 0,710 & 0,779 & 0,009 & 0,004 & 0,235 & 0,007 & 0,137 \\
\hline AIBB & 0,057 & 0,057 & 0,935 & 0,111 & 0,491 & 0,524 & 0,022 & 0,001 & 0,479 & 0,005 & 0,084 \\
\hline PIBB & 0,075 & 0,075 & 0,905 & 0,109 & 0,664 & 0,734 & 0,009 & 0,001 & 0,301 & 0,010 & 0,138 \\
\hline BR & 0,139 & 0,122 & 0,806 & 0,248 & 0,690 & 0,856 & 0,023 & 0,017 & 0,160 & 0,023 & 0,166 \\
\hline ASBB & 0,226 & 0,089 & 0,745 & 0,116 & 0,360 & 0,483 & 0,015 & 0,138 & 0,282 & 0,011 & 0,050 \\
\hline ABIB & 0,101 & 0,028 & 0,868 & 0,206 & 0,512 & 0,589 & 0,110 & 0,073 & 0,309 & 0,001 & 0,006 \\
\hline BISB & 0,086 & $-0,053$ & 0,899 & 0,118 & 0,480 & 0,534 & 0,271 & 0,139 & 0,259 & 0,007 & 0,078 \\
\hline DIB & 0,144 & 0,105 & 0,721 & 0,121 & 0,495 & 0,686 & 0,101 & 0,039 & 0,285 & 0,015 & 0,105 \\
\hline SIB & 0,209 & 0,167 & 0,608 & 0,057 & 0,576 & 0,948 & 0,057 & 0,042 & 0,236 & 0,014 & 0,068 \\
\hline EIB & 0,105 & 0,102 & 0,734 & 0,050 & 0,545 & 0,742 & 0,188 & 0,003 & 0,350 & 0,004 & 0,034 \\
\hline ADIB & 0,127 & 0,106 & 0,792 & 0,060 & 0,599 & 0,755 & 0,070 & 0,021 & 0,280 & 0,014 & 0,111 \\
\hline AUB & 0,102 & 0,066 & 0,883 & 0,022 & 0,676 & 0,766 & 0,031 & 0,036 & 0,288 & 0,013 & 0,131 \\
\hline BB & 0,123 & 0,066 & 0,864 & 0,031 & 0,675 & 0,781 & 0,019 & 0,057 & 0,262 & 0,006 & 0,047 \\
\hline KFH & 0,128 & $-0,004$ & 0,779 & 0,075 & 0,403 & 0,517 & 0,130 & 0,132 & 0,292 & 0,009 & 0,072 \\
\hline BAJ & 0,096 & 0,074 & 0,874 & 0,210 & 0,583 & 0,667 & 0,012 & 0,022 & 0,173 & 0,011 & 0,114 \\
\hline ARB & 0,137 & 0,122 & 0,840 & 0,141 & 0,677 & 0,805 & 0,016 & 0,015 & 0,198 & 0,027 & 0,194 \\
\hline SB & 0,170 & 0,161 & 0,809 & 0,294 & 0,553 & 0,684 & 0,018 & 0,009 & 0,123 & 0,022 & 0,130 \\
\hline BSF & 0,137 & 0,132 & 0,795 & 0,202 & 0,655 & 0,823 & 0,014 & 0,005 & 0,116 & 0,014 & 0,104 \\
\hline ATKB & 0,087 & 0,060 & 0,728 & 0,058 & 0,696 & 0,957 & 0,023 & 0,027 & 0,227 & 0,014 & 0,161 \\
\hline KTKB & 0,089 & 0,061 & 0,658 & 0,056 & 0,627 & 0,953 & 0,024 & 0,028 & 0,318 & 0,012 & 0,130 \\
\hline TFKB & 0,100 & 0,060 & 0,603 & 0,058 & 0,694 & 1,152 & 0,025 & 0,040 & 0,249 & 0,013 & 0,131 \\
\hline
\end{tabular}

Tablo 16: 2014 Y1l Karar Matrisi

\begin{tabular}{|c|c|c|c|c|c|c|c|c|c|c|c|}
\hline $\mathbf{2 0 1 4}$ & $\mathbf{1}$ & $\mathbf{2}$ & $\mathbf{3}$ & $\mathbf{4}$ & $\mathbf{5}$ & $\mathbf{6}$ & $\mathbf{7}$ & $\mathbf{8}$ & $\mathbf{9}$ & $\mathbf{1 0}$ & $\mathbf{1 1}$ \\
\hline CIMB & 0,064 & 0,059 & 0,902 & 0,129 & 0,728 & 0,807 & 0,013 & 0,005 & 0,219 & 0,008 & 0,122 \\
\hline AIBB & 0,061 & 0,060 & 0,937 & 0,127 & 0,563 & 0,601 & 0,018 & 0,001 & 0,382 & 0,005 & 0,086 \\
\hline PIBB & 0,070 & 0,069 & 0,900 & 0,231 & 0,667 & 0,740 & 0,009 & 0,001 & 0,256 & 0,009 & 0,133 \\
\hline BR & 0,143 & 0,126 & 0,787 & 0,259 & 0,677 & 0,860 & 0,021 & 0,017 & 0,170 & 0,022 & 0,155 \\
\hline ASBB & 0,168 & 0,086 & 0,732 & 0,075 & 0,313 & 0,427 & 0,055 & 0,082 & 0,310 & 0,008 & 0,048 \\
\hline ABIB & 0,093 & 0,030 & 0,868 & 0,241 & 0,522 & 0,602 & 0,110 & 0,063 & 0,171 & 0,001 & 0,012 \\
\hline BISB & 0,090 & $-0,026$ & 0,891 & 0,141 & 0,599 & 0,673 & 0,125 & 0,116 & 0,138 & 0,011 & 0,118 \\
\hline DIB & 0,143 & 0,107 & 0,777 & 0,147 & 0,597 & 0,768 & 0,072 & 0,036 & 0,167 & 0,023 & 0,158 \\
\hline SIB & 0,176 & 0,140 & 0,655 & 0,061 & 0,556 & 0,849 & 0,055 & 0,036 & 0,241 & 0,014 & 0,082 \\
\hline EIB & 0,105 & 0,102 & 0,766 & 0,075 & 0,608 & 0,794 & 0,113 & 0,003 & 0,260 & 0,008 & 0,081 \\
\hline ADIB & 0,122 & 0,096 & 0,807 & 0,057 & 0,652 & 0,809 & 0,042 & 0,026 & 0,224 & 0,016 & 0,128 \\
\hline
\end{tabular}




\begin{tabular}{|c|c|c|c|c|c|c|c|c|c|c|c|}
\hline AUB & 0,094 & 0,067 & 0,893 & 0,042 & 0,690 & 0,773 & 0,031 & 0,028 & 0,280 & 0,013 & 0,139 \\
\hline BB & 0,114 & 0,066 & 0,876 & 0,048 & 0,682 & 0,778 & 0,011 & 0,048 & 0,266 & 0,011 & 0,095 \\
\hline KFH & 0,122 & 0,003 & 0,834 & 0,080 & 0,473 & 0,566 & 0,110 & 0,119 & 0,361 & 0,009 & 0,076 \\
\hline BAJ & 0,093 & 0,072 & 0,876 & 0,170 & 0,620 & 0,707 & 0,009 & 0,021 & 0,172 & 0,009 & 0,093 \\
\hline ARB & 0,136 & 0,121 & 0,839 & 0,138 & 0,669 & 0,798 & 0,013 & 0,016 & 0,163 & 0,022 & 0,163 \\
\hline SB & 0,179 & 0,169 & 0,797 & 0,297 & 0,571 & 0,716 & 0,013 & 0,010 & 0,102 & 0,023 & 0,129 \\
\hline BSF & 0,140 & 0,136 & 0,790 & 0,239 & 0,617 & 0,781 & 0,010 & 0,004 & 0,117 & 0,019 & 0,133 \\
\hline ATKB & 0,078 & 0,052 & 0,722 & 0,063 & 0,671 & 0,930 & 0,021 & 0,026 & 0,236 & 0,011 & 0,146 \\
\hline KTKB & 0,089 & 0,064 & 0,651 & 0,066 & 0,605 & 0,929 & 0,023 & 0,025 & 0,338 & 0,011 & 0,123 \\
\hline TFKB & 0,094 & 0,051 & 0,571 & 0,077 & 0,688 & 1,206 & 0,026 & 0,043 & 0,231 & 0,010 & 0,106 \\
\hline
\end{tabular}

Tablo 17: 2015 Y1l Karar Matrisi

\begin{tabular}{|c|c|c|c|c|c|c|c|c|c|c|c|}
\hline 2015 & $\mathbf{1}$ & $\mathbf{2}$ & $\mathbf{3}$ & $\mathbf{4}$ & $\mathbf{5}$ & $\mathbf{6}$ & $\mathbf{7}$ & $\mathbf{8}$ & $\mathbf{9}$ & $\mathbf{1 0}$ & $\mathbf{1 1}$ \\
\hline CIMB & 0,066 & 0,061 & 0,886 & 0,124 & 0,739 & 0,834 & 0,011 & 0,005 & 0,191 & 0,007 & 0,112 \\
\hline AIBB & 0,071 & 0,071 & 0,825 & 0,116 & 0,687 & 0,833 & 0,015 & 0,001 & 0,256 & 0,006 & 0,089 \\
\hline PIBB & 0,065 & 0,064 & 0,907 & 0,201 & 0,695 & 0,766 & 0,007 & 0,000 & 0,210 & 0,007 & 0,115 \\
\hline BR & 0,152 & 0,135 & 0,789 & 0,260 & 0,683 & 0,866 & 0,019 & 0,017 & 0,174 & 0,020 & 0,130 \\
\hline ASBB & 0,193 & 0,100 & 0,739 & 0,075 & 0,405 & 0,548 & 0,086 & 0,093 & 0,343 & 0,006 & 0,033 \\
\hline ABIB & 0,094 & 0,036 & 0,857 & 0,243 & 0,556 & 0,648 & 0,067 & 0,058 & 0,148 & 0,003 & 0,035 \\
\hline BISB & 0,112 & 0,022 & 0,871 & 0,134 & 0,624 & 0,717 & 0,088 & 0,090 & 0,138 & 0,011 & 0,102 \\
\hline DIB & 0,152 & 0,115 & 0,765 & 0,146 & 0,649 & 0,848 & 0,044 & 0,038 & 0,123 & 0,026 & 0,168 \\
\hline SIB & 0,157 & 0,126 & 0,636 & 0,079 & 0,547 & 0,861 & 0,069 & 0,031 & 0,225 & 0,014 & 0,087 \\
\hline EIB & 0,096 & 0,093 & 0,796 & 0,043 & 0,642 & 0,807 & 0,096 & 0,003 & 0,275 & 0,012 & 0,126 \\
\hline ADIB & 0,127 & 0,102 & 0,828 & 0,074 & 0,662 & 0,800 & 0,037 & 0,025 & 0,197 & 0,016 & 0,128 \\
\hline AUB & 0,092 & 0,073 & 0,894 & 0,036 & 0,687 & 0,768 & 0,025 & 0,019 & 0,288 & 0,011 & 0,119 \\
\hline BB & 0,102 & 0,063 & 0,888 & 0,045 & 0,693 & 0,781 & 0,009 & 0,039 & 0,263 & 0,011 & 0,110 \\
\hline KFH & 0,124 & 0,027 & 0,833 & 0,080 & 0,492 & 0,591 & 0,095 & 0,097 & 0,370 & 0,011 & 0,092 \\
\hline BAJ & 0,117 & 0,104 & 0,849 & 0,177 & 0,662 & 0,779 & 0,008 & 0,013 & 0,133 & 0,020 & 0,174 \\
\hline ARB & 0,148 & 0,130 & 0,826 & 0,126 & 0,666 & 0,806 & 0,016 & 0,018 & 0,171 & 0,023 & 0,153 \\
\hline SB & 0,172 & 0,162 & 0,810 & 0,296 & 0,552 & 0,681 & 0,009 & 0,010 & 0,126 & 0,022 & 0,129 \\
\hline BSF & 0,150 & 0,145 & 0,780 & 0,154 & 0,672 & 0,861 & 0,009 & 0,004 & 0,142 & 0,022 & 0,147 \\
\hline ATKB & 0,071 & 0,045 & 0,688 & 0,062 & 0,628 & 0,912 & 0,025 & 0,026 & 0,286 & 0,010 & 0,146 \\
\hline KTKB & 0,081 & 0,056 & 0,669 & 0,058 & 0,615 & 0,919 & 0,017 & 0,025 & 0,323 & 0,011 & 0,131 \\
\hline TFKB & 0,082 & 0,022 & 0,575 & 0,083 & 0,700 & 1,218 & 0,046 & 0,065 & 0,205 & 0,007 & 0,083 \\
\hline
\end{tabular}

Tablo 18: 2016 Y1lı Karar Matrisi

\begin{tabular}{|c|c|c|c|c|c|c|c|c|c|c|c|}
\hline $\mathbf{2 0 1 6}$ & $\mathbf{1}$ & $\mathbf{2}$ & $\mathbf{3}$ & $\mathbf{4}$ & $\mathbf{5}$ & $\mathbf{6}$ & $\mathbf{7}$ & $\mathbf{8}$ & $\mathbf{9}$ & $\mathbf{1 0}$ & $\mathbf{1 1}$ \\
\hline CIMB & 0,062 & 0,059 & 0,873 & 0,128 & 0,708 & 0,811 & 0,010 & 0,004 & 0,191 & 0,008 & 0,131 \\
\hline
\end{tabular}




\begin{tabular}{|c|c|c|c|c|c|c|c|c|c|c|c|}
\hline AIBB & 0,076 & 0,075 & 0,770 & 0,125 & 0,779 & 1,012 & 0,008 & 0,001 & 0,189 & 0,007 & 0,097 \\
\hline PIBB & 0,072 & 0,061 & 0,902 & 0,194 & 0,750 & 0,831 & 0,006 & 0,011 & 0,147 & 0,008 & 0,113 \\
\hline BR & 0,154 & 0,137 & 0,794 & 0,266 & 0,683 & 0,860 & 0,020 & 0,016 & 0,178 & 0,016 & 0,107 \\
\hline ASBB & 0,193 & 0,130 & 0,771 & 0,073 & 0,397 & 0,515 & 0,138 & 0,063 & 0,400 & 0,010 & 0,050 \\
\hline ABIB & 0,087 & 0,018 & 0,855 & 0,230 & 0,562 & 0,657 & 0,082 & 0,069 & 0,133 & 0,001 & 0,011 \\
\hline BISB & 0,114 & 0,045 & 0,871 & 0,143 & 0,652 & 0,749 & 0,080 & 0,069 & 0,124 & 0,008 & 0,072 \\
\hline DIB & 0,156 & 0,121 & 0,759 & 0,144 & 0,657 & 0,866 & 0,039 & 0,034 & 0,121 & 0,023 & 0,149 \\
\hline SIB & 0,145 & 0,117 & 0,661 & 0,122 & 0,510 & 0,771 & 0,071 & 0,028 & 0,234 & 0,014 & 0,095 \\
\hline EIB & 0,113 & 0,109 & 0,725 & 0,025 & 0,614 & 0,846 & 0,099 & 0,004 & 0,328 & 0,002 & 0,016 \\
\hline ADIB & 0,126 & 0,101 & 0,850 & 0,086 & 0,640 & 0,752 & 0,042 & 0,025 & 0,211 & 0,016 & 0,126 \\
\hline AUB & 0,121 & 0,103 & 0,865 & 0,055 & 0,733 & 0,847 & 0,026 & 0,017 & 0,244 & 0,011 & 0,091 \\
\hline BB & 0,122 & 0,089 & 0,868 & 0,052 & 0,723 & 0,833 & 0,008 & 0,032 & 0,327 & 0,012 & 0,098 \\
\hline KFH & 0,124 & 0,044 & 0,795 & 0,088 & 0,496 & 0,623 & 0,083 & 0,080 & 0,353 & 0,010 & 0,079 \\
\hline BAJ & 0,122 & 0,109 & 0,832 & 0,246 & 0,635 & 0,763 & 0,011 & 0,013 & 0,099 & 0,013 & 0,108 \\
\hline ARB & 0,153 & 0,134 & 0,829 & 0,100 & 0,662 & 0,799 & 0,013 & 0,019 & 0,202 & 0,024 & 0,156 \\
\hline SB & 0,184 & 0,173 & 0,790 & 0,222 & 0,541 & 0,685 & 0,009 & 0,011 & 0,203 & 0,022 & 0,118 \\
\hline BSF & 0,146 & 0,142 & 0,800 & 0,118 & 0,636 & 0,795 & 0,013 & 0,004 & 0,225 & 0,017 & 0,118 \\
\hline ATKB & 0,069 & 0,033 & 0,705 & 0,064 & 0,665 & 0,943 & 0,051 & 0,037 & 0,262 & 0,007 & 0,095 \\
\hline KTKB & 0,081 & 0,058 & 0,658 & 0,078 & 0,586 & 0,891 & 0,026 & 0,023 & 0,346 & 0,011 & 0,139 \\
\hline TFKB & 0,094 & 0,015 & 0,543 & 0,106 & 0,660 & 1,215 & 0,054 & 0,080 & 0,247 & 0,008 & 0,081 \\
\hline
\end{tabular}

Tablo 19: 2017 Y1lı Karar Matrisi

\begin{tabular}{|c|c|c|c|c|c|c|c|c|c|c|c|}
\hline $\mathbf{2 0 1 7}$ & $\mathbf{1}$ & $\mathbf{2}$ & $\mathbf{3}$ & $\mathbf{4}$ & $\mathbf{5}$ & $\mathbf{6}$ & $\mathbf{7}$ & $\mathbf{8}$ & $\mathbf{9}$ & $\mathbf{1 0}$ & $\mathbf{1 1}$ \\
\hline CIMB & 0,056 & 0,053 & 0,893 & 0,123 & 0,675 & 0,756 & 0,007 & 0,003 & 0,234 & 0,008 & 0,134 \\
\hline AIBB & 0,088 & 0,087 & 0,771 & 0,119 & 0,767 & 0,994 & 0,009 & 0,000 & 0,190 & 0,004 & 0,051 \\
\hline PIBB & 0,073 & 0,064 & 0,902 & 0,166 & 0,730 & 0,810 & 0,006 & 0,010 & 0,177 & 0,007 & 0,098 \\
\hline BR & 0,158 & 0,141 & 0,789 & 0,291 & 0,656 & 0,831 & 0,023 & 0,016 & 0,216 & 0,018 & 0,115 \\
\hline ASBB & 0,191 & 0,127 & 0,777 & 0,070 & 0,464 & 0,597 & 0,050 & 0,064 & 0,357 & 0,011 & 0,059 \\
\hline ABIB & 0,083 & 0,013 & 0,836 & 0,225 & 0,600 & 0,717 & 0,095 & 0,071 & 0,139 & $-0,002$ & $-0,028$ \\
\hline BISB & 0,100 & 0,044 & 0,891 & 0,210 & 0,603 & 0,677 & 0,074 & 0,055 & 0,123 & 0,008 & 0,083 \\
\hline DIB & 0,139 & 0,106 & 0,782 & 0,125 & 0,643 & 0,823 & 0,034 & 0,033 & 0,157 & 0,022 & 0,156 \\
\hline SIB & 0,144 & 0,122 & 0,689 & 0,131 & 0,567 & 0,822 & 0,059 & 0,022 & 0,184 & 0,012 & 0,087 \\
\hline EIB & 0,118 & 0,115 & 0,761 & 0,029 & 0,547 & 0,718 & 0,114 & 0,003 & 0,395 & 0,011 & 0,096 \\
\hline ADIB & 0,134 & 0,107 & 0,841 & 0,094 & 0,621 & 0,738 & 0,052 & 0,028 & 0,214 & 0,019 & 0,139 \\
\hline AUB & 0,128 & 0,106 & 0,855 & 0,059 & 0,729 & 0,853 & 0,014 & 0,022 & 0,245 & 0,012 & 0,095 \\
\hline BB & 0,114 & 0,073 & 0,873 & 0,059 & 0,725 & 0,830 & 0,008 & 0,041 & 0,231 & 0,012 & 0,105 \\
\hline KFH & 0,122 & 0,049 & 0,797 & 0,100 & 0,531 & 0,666 & 0,030 & 0,073 & 0,341 & 0,012 & 0,101 \\
\hline BAJ & 0,129 & 0,109 & 0,827 & 0,298 & 0,583 & 0,705 & 0,013 & 0,020 & 0,093 & 0,013 & 0,097 \\
\hline ARB & 0,162 & 0,140 & 0,812 & 0,106 & 0,681 & 0,838 & 0,008 & 0,023 & 0,172 & 0,027 & 0,164 \\
\hline SB & 0,196 & 0,185 & 0,767 & 0,281 & 0,517 & 0,674 & 0,010 & 0,012 & 0,159 & 0,022 & 0,112 \\
\hline BSF & 0,164 & 0,160 & 0,798 & 0,131 & 0,632 & 0,792 & 0,028 & 0,004 & 0,213 & 0,018 & 0,112 \\
\hline
\end{tabular}




\begin{tabular}{|l|l|l|l|l|l|l|l|l|l|l|l|}
\hline ATKB & 0,068 & 0,034 & 0,699 & 0,079 & 0,675 & 0,966 & 0,050 & 0,034 & 0,265 & 0,007 & 0,096 \\
\hline KTKB & 0,080 & 0,061 & 0,698 & 0,082 & 0,631 & 0,904 & 0,020 & 0,019 & 0,301 & 0,012 & 0,147 \\
\hline TFKB & 0,104 & 0,013 & 0,564 & 0,113 & 0,648 & 1,150 & 0,056 & 0,091 & 0,259 & 0,010 & 0,092 \\
\hline
\end{tabular}

Tablo 20: 2018 Y1lı Karar Matrisi

\begin{tabular}{|c|c|c|c|c|c|c|c|c|c|c|c|}
\hline 2018 & $\mathbf{1}$ & $\mathbf{2}$ & $\mathbf{3}$ & $\mathbf{4}$ & $\mathbf{5}$ & $\mathbf{6}$ & $\mathbf{7}$ & $\mathbf{8}$ & $\mathbf{9}$ & $\mathbf{1 0}$ & $\mathbf{1 1}$ \\
\hline CIMB & 0,057 & 0,054 & 0,905 & 0,131 & 0,724 & 0,800 & 0,006 & 0,003 & 0,142 & 0,009 & 0,151 \\
\hline AIBB & 0,072 & 0,072 & 0,786 & 0,111 & 0,734 & 0,934 & 0,029 & 0,001 & 0,237 & 0,004 & 0,061 \\
\hline PIBB & 0,073 & 0,064 & 0,895 & 0,191 & 0,734 & 0,820 & 0,006 & 0,009 & 0,086 & 0,008 & 0,104 \\
\hline BR & 0,167 & 0,147 & 0,782 & 0,311 & 0,646 & 0,826 & 0,022 & 0,020 & 0,018 & 0,016 & 0,098 \\
\hline ASBB & 0,178 & 0,106 & 0,794 & 0,063 & 0,333 & 0,419 & 0,057 & 0,072 & 0,351 & 0,011 & 0,061 \\
\hline ABIB & 0,112 & 0,039 & 0,828 & 0,250 & 0,582 & 0,703 & 0,100 & 0,073 & 0,145 & $-0,008$ & $-0,075$ \\
\hline BISB & 0,092 & 0,045 & 0,614 & 0,187 & 0,599 & 0,975 & 0,124 & 0,047 & 0,158 & 0,009 & 0,097 \\
\hline DIB & 0,153 & 0,118 & 0,755 & 0,147 & 0,647 & 0,857 & 0,035 & 0,035 & 0,138 & 0,022 & 0,147 \\
\hline SIB & 0,120 & 0,101 & 0,737 & 0,139 & 0,539 & 0,731 & 0,058 & 0,019 & 0,216 & 0,011 & 0,095 \\
\hline EIB & 0,124 & 0,120 & 0,784 & 0,043 & 0,620 & 0,791 & 0,091 & 0,004 & 0,316 & 0,016 & 0,128 \\
\hline ADIB & 0,142 & 0,115 & 0,835 & 0,109 & 0,628 & 0,753 & 0,050 & 0,027 & 0,192 & 0,020 & 0,141 \\
\hline AUB & 0,126 & 0,105 & 0,854 & 0,068 & 0,715 & 0,838 & 0,013 & 0,020 & 0,261 & 0,013 & 0,104 \\
\hline BB & 0,112 & 0,087 & 0,879 & 0,088 & 0,751 & 0,854 & 0,009 & 0,025 & 0,218 & 0,013 & 0,116 \\
\hline KFH & 0,117 & 0,048 & 0,814 & 0,104 & 0,517 & 0,635 & 0,024 & 0,068 & 0,376 & 0,015 & 0,127 \\
\hline BAJ & 0,154 & 0,136 & 0,798 & 0,330 & 0,560 & 0,702 & 0,016 & 0,018 & 0,086 & 0,005 & 0,034 \\
\hline ARB & 0,133 & 0,109 & 0,827 & 0,118 & 0,637 & 0,769 & 0,010 & 0,024 & 0,208 & 0,010 & 0,078 \\
\hline SB & 0,184 & 0,172 & 0,774 & 0,304 & 0,495 & 0,639 & 0,013 & 0,012 & 0,187 & 0,024 & 0,131 \\
\hline BSF & 0,162 & 0,156 & 0,791 & 0,159 & 0,634 & 0,801 & 0,030 & 0,006 & 0,194 & 0,007 & 0,045 \\
\hline ATKB & 0,077 & 0,001 & 0,678 & 0,334 & 0,620 & 0,915 & 0,072 & 0,031 & 0,290 & 0,003 & 0,041 \\
\hline KTKB & 0,073 & 0,001 & 0,727 & 0,317 & 0,611 & 0,840 & 0,007 & 0,000 & 0,232 & 0,012 & 0,160 \\
\hline TFKB & 0,092 & 0,001 & 0,571 & 0,290 & 0,648 & 1,135 & 0,057 & 0,000 & 0,213 & 0,009 & 0,103 \\
\hline
\end{tabular}

Tablo 21: 2019 Y1lı Karar Matrisi

\begin{tabular}{|c|c|c|c|c|c|c|c|c|c|c|c|}
\hline $\mathbf{2 0 1 9}$ & $\mathbf{1}$ & $\mathbf{2}$ & $\mathbf{3}$ & $\mathbf{4}$ & $\mathbf{5}$ & $\mathbf{6}$ & $\mathbf{7}$ & $\mathbf{8}$ & $\mathbf{9}$ & $\mathbf{1 0}$ & $\mathbf{1 1}$ \\
\hline CIMB & 0,059 & 0,057 & 0,904 & 0,162 & 0,741 & 0,820 & 0,016 & 0,002 & 0,120 & 0,007 & 0,124 \\
\hline AIBB & 0,083 & 0,082 & 0,768 & 0,103 & 0,800 & 1,041 & 0,033 & 0,001 & 0,171 & 0,003 & 0,035 \\
\hline PIBB & 0,073 & 0,064 & 0,898 & 0,196 & 0,722 & 0,804 & 0,006 & 0,009 & 0,104 & 0,007 & 0,098 \\
\hline BR & 0,178 & 0,158 & 0,777 & 0,303 & 0,647 & 0,834 & 0,020 & 0,021 & 0,022 & 0,015 & 0,083 \\
\hline ASBB & 0,154 & 0,099 & 0,825 & 0,053 & 0,355 & 0,430 & 0,042 & 0,055 & 0,333 & 0,010 & 0,067 \\
\hline ABIB & 0,120 & 0,064 & 0,831 & 0,336 & 0,438 & 0,527 & 0,114 & 0,057 & 0,089 & 0,002 & 0,019 \\
\hline BISB & 0,099 & 0,057 & 0,088 & 0,201 & 0,637 & 7,207 & 0,164 & 0,042 & 0,113 & 0,005 & 0,051 \\
\hline DIB & 0,150 & 0,112 & 0,749 & 0,149 & 0,651 & 0,869 & 0,041 & 0,038 & 0,119 & 0,022 & 0,147 \\
\hline SIB & 0,162 & 0,142 & 0,699 & 0,126 & 0,542 & 0,775 & 0,054 & 0,020 & 0,224 & 0,012 & 0,072 \\
\hline
\end{tabular}




\begin{tabular}{|c|c|c|c|c|c|c|c|c|c|c|c|}
\hline EIB & 0,128 & 0,122 & 0,776 & 0,059 & 0,579 & 0,746 & 0,083 & 0,006 & 0,329 & 0,016 & 0,128 \\
\hline ADIB & 0,152 & 0,121 & 0,824 & 0,103 & 0,644 & 0,781 & 0,070 & 0,030 & 0,184 & 0,021 & 0,136 \\
\hline AUB & 0,119 & 0,101 & 0,861 & 0,070 & 0,694 & 0,806 & 0,013 & 0,018 & 0,284 & 0,013 & 0,107 \\
\hline BB & 0,123 & 0,092 & 0,865 & 0,077 & 0,703 & 0,813 & 0,009 & 0,031 & 0,259 & 0,012 & 0,096 \\
\hline KFH & 0,116 & 0,053 & 0,824 & 0,128 & 0,481 & 0,584 & 0,023 & 0,063 & 0,422 & 0,014 & 0,117 \\
\hline BAJ & 0,134 & 0,113 & 0,820 & 0,320 & 0,574 & 0,700 & 0,014 & 0,020 & 0,080 & 0,011 & 0,086 \\
\hline ARB & 0,133 & 0,106 & 0,819 & 0,122 & 0,650 & 0,794 & 0,009 & 0,027 & 0,186 & 0,026 & 0,198 \\
\hline SB & 0,178 & 0,166 & 0,766 & 0,345 & 0,554 & 0,723 & 0,014 & 0,012 & 0,085 & 0,016 & 0,088 \\
\hline BSF & 0,185 & 0,175 & 0,759 & 0,202 & 0,706 & 0,930 & 0,027 & 0,010 & 0,072 & 0,017 & 0,095 \\
\hline ATKB & 0,074 & 0,040 & 0,774 & 0,335 & 0,596 & 0,770 & 0,073 & 0,030 & 0,296 & 0,001 & 0,017 \\
\hline KTKB & 0,065 & 0,001 & 0,819 & 0,409 & 0,529 & 0,646 & 0,009 & 0,000 & 0,409 & 0,011 & 0,163 \\
\hline TFKB & 0,092 & 0,001 & 0,762 & 0,343 & 0,621 & 0,815 & 0,082 & 0,000 & 0,343 & 0,007 & 0,078 \\
\hline
\end{tabular}

Tablo 22: 2013 Y1lı Genel Karar Matrisi

\begin{tabular}{|c|c|c|c|c|c|c|c|c|c|c|c|}
\hline ÜLKELER (2013) & $\mathbf{1}$ & $\mathbf{2}$ & $\mathbf{3}$ & $\mathbf{4}$ & $\mathbf{5}$ & $\mathbf{6}$ & $\mathbf{7}$ & $\mathbf{8}$ & $\mathbf{9}$ & $\mathbf{1 0}$ & $\mathbf{1 1}$ \\
\hline SUUDİ ARABİSTAN & 0,13 & 0,12 & 0,83 & 0,21 & 0,62 & 0,74 & 0,01 & 0,01 & 0,15 & 0,02 & 0,14 \\
\hline MALEZYA & 0,08 & 0,08 & 0,89 & 0,14 & 0,64 & 0,72 & 0,02 & 0,01 & 0,29 & 0,01 & 0,13 \\
\hline BAE & 0,15 & 0,12 & 0,71 & 0,07 & 0,55 & 0,78 & 0,10 & 0,03 & 0,29 & 0,01 & 0,08 \\
\hline KUVEYT & 0,12 & 0,04 & 0,84 & 0,04 & 0,58 & 0,69 & 0,06 & 0,08 & 0,28 & 0,01 & 0,08 \\
\hline TÜRKİYE & 0,09 & 0,06 & 0,66 & 0,06 & 0,67 & 1,02 & 0,02 & 0,03 & 0,26 & 0,01 & 0,14 \\
\hline BAHREYN & 0,14 & 0,02 & 0,84 & 0,15 & 0,45 & 0,54 & 0,13 & 0,12 & 0,28 & 0,01 & 0,04 \\
\hline
\end{tabular}

Tablo 23: 2014 Yılı Genel Karar Matrisi

\begin{tabular}{|c|c|c|c|c|c|c|c|c|c|c|c|}
\hline ÜLKELER (2014) & $\mathbf{1}$ & $\mathbf{2}$ & $\mathbf{3}$ & $\mathbf{4}$ & $\mathbf{5}$ & $\mathbf{6}$ & $\mathbf{7}$ & $\mathbf{8}$ & $\mathbf{9}$ & $\mathbf{1 0}$ & $\mathbf{1 1}$ \\
\hline SUUDİ ARABİSTAN & 0,14 & 0,12 & 0,83 & 0,21 & 0,62 & 0,75 & 0,01 & 0,01 & 0,14 & 0,02 & 0,13 \\
\hline MALEZYA & 0,08 & 0,08 & 0,88 & 0,19 & 0,66 & 0,75 & 0,02 & 0,01 & 0,26 & 0,01 & 0,12 \\
\hline BAE & 0,14 & 0,11 & 0,75 & 0,08 & 0,60 & 0,81 & 0,07 & 0,03 & 0,22 & 0,02 & 0,11 \\
\hline KUVEYT & 0,11 & 0,05 & 0,87 & 0,06 & 0,61 & 0,71 & 0,05 & 0,06 & 0,30 & 0,01 & 0,10 \\
\hline TÜRKIYYE & 0,09 & 0,06 & 0,65 & 0,07 & 0,65 & 1,02 & 0,02 & 0,03 & 0,27 & 0,01 & 0,12 \\
\hline BAHREYN & 0,12 & 0,03 & 0,83 & 0,15 & 0,48 & 0,57 & 0,10 & 0,09 & 0,21 & 0,01 & 0,06 \\
\hline
\end{tabular}


Tablo 24: 2015 Y1lı Genel Karar Matrisi

\begin{tabular}{|c|c|c|c|c|c|c|c|c|c|c|c|}
\hline ÜLKELER (2015) & $\mathbf{1}$ & $\mathbf{2}$ & $\mathbf{3}$ & $\mathbf{4}$ & $\mathbf{5}$ & $\mathbf{6}$ & $\mathbf{7}$ & $\mathbf{8}$ & $\mathbf{9}$ & $\mathbf{1 0}$ & $\mathbf{1 1}$ \\
\hline SUUDİ ARABİSTAN & 0,15 & 0,14 & 0,82 & 0,19 & 0,64 & 0,78 & 0,01 & 0,01 & 0,14 & 0,02 & 0,15 \\
\hline MALEZYA & 0,09 & 0,08 & 0,85 & 0,18 & 0,70 & 0,82 & 0,01 & 0,01 & 0,21 & 0,01 & 0,11 \\
\hline BAE & 0,13 & 0,11 & 0,76 & 0,09 & 0,63 & 0,83 & 0,06 & 0,02 & 0,21 & 0,02 & 0,13 \\
\hline KUVEYT & 0,11 & 0,05 & 0,87 & 0,05 & 0,62 & 0,71 & 0,04 & 0,05 & 0,31 & 0,01 & 0,11 \\
\hline TÜRKİYE & 0,08 & 0,04 & 0,64 & 0,07 & 0,65 & 1,02 & 0,03 & 0,04 & 0,27 & 0,01 & 0,12 \\
\hline BAHREYN & 0,13 & 0,05 & 0,82 & 0,15 & 0,53 & 0,64 & 0,08 & 0,08 & 0,21 & 0,01 & 0,06 \\
\hline
\end{tabular}

Tablo 25: 2016 Y1lı Genel Karar Matrisi

\begin{tabular}{|c|c|c|c|c|c|c|c|c|c|c|c|}
\hline ÜLKELER (2016) & $\mathbf{1}$ & $\mathbf{2}$ & $\mathbf{3}$ & $\mathbf{4}$ & $\mathbf{5}$ & $\mathbf{6}$ & $\mathbf{7}$ & $\mathbf{8}$ & $\mathbf{9}$ & $\mathbf{1 0}$ & $\mathbf{1 1}$ \\
\hline SUUDİ ARABİSTAN & 0,15 & 0,14 & 0,81 & 0,17 & 0,62 & 0,76 & 0,01 & 0,01 & 0,18 & 0,02 & 0,12 \\
\hline MALEZYA & 0,09 & 0,08 & 0,83 & 0,18 & 0,73 & 0,88 & 0,01 & 0,01 & 0,18 & 0,01 & 0,11 \\
\hline BAE & 0,13 & 0,11 & 0,75 & 0,09 & 0,60 & 0,81 & 0,06 & 0,02 & 0,22 & 0,01 & 0,10 \\
\hline KUVEYT & 0,12 & 0,08 & 0,84 & 0,07 & 0,65 & 0,77 & 0,04 & 0,04 & 0,31 & 0,01 & 0,09 \\
\hline TÜRKİYE & 0,08 & 0,04 & 0,64 & 0,08 & 0,64 & 1,02 & 0,04 & 0,05 & 0,28 & 0,01 & 0,10 \\
\hline BAHREYN & 0,13 & 0,06 & 0,83 & 0,15 & 0,54 & 0,64 & 0,10 & 0,07 & 0,22 & 0,01 & 0,04 \\
\hline
\end{tabular}

Tablo 26: 2017 Y1lı Genel Karar Matrisi

\begin{tabular}{|c|c|c|c|c|c|c|c|c|c|c|c|}
\hline ÜLKELER (2017) & $\mathbf{1}$ & $\mathbf{2}$ & $\mathbf{3}$ & $\mathbf{4}$ & $\mathbf{5}$ & $\mathbf{6}$ & $\mathbf{7}$ & $\mathbf{8}$ & $\mathbf{9}$ & $\mathbf{1 0}$ & $\mathbf{1 1}$ \\
\hline SUUDİ ARABİSTAN & 0,16 & 0,15 & 0,80 & 0,20 & 0,60 & 0,75 & 0,01 & 0,01 & 0,16 & 0,02 & 0,12 \\
\hline MALEZYA & 0,09 & 0,09 & 0,84 & 0,17 & 0,71 & 0,85 & 0,01 & 0,01 & 0,20 & 0,01 & 0,10 \\
\hline BAE & 0,13 & 0,11 & 0,77 & 0,09 & 0,59 & 0,78 & 0,06 & 0,02 & 0,24 & 0,02 & 0,12 \\
\hline KUVEYT & 0,12 & 0,08 & 0,84 & 0,07 & 0,66 & 0,78 & 0,02 & 0,05 & 0,27 & 0,01 & 0,10 \\
\hline TÜRKİYE & 0,08 & 0,04 & 0,65 & 0,09 & 0,65 & 1,01 & 0,04 & 0,05 & 0,28 & 0,01 & 0,11 \\
\hline BAHREYN & 0,12 & 0,06 & 0,83 & 0,17 & 0,56 & 0,66 & 0,07 & 0,06 & 0,21 & 0,01 & 0,04 \\
\hline
\end{tabular}


Tablo 27: 2018 Y1lı Genel Karar Matrisi

\begin{tabular}{|c|c|c|c|c|c|c|c|c|c|c|c|}
\hline ÜLKELER (2018) & $\mathbf{1}$ & $\mathbf{2}$ & $\mathbf{3}$ & $\mathbf{4}$ & $\mathbf{5}$ & $\mathbf{6}$ & $\mathbf{7}$ & $\mathbf{8}$ & $\mathbf{9}$ & $\mathbf{1 0}$ & $\mathbf{1 1}$ \\
\hline SUUDİ ARABİSTAN & 0,16 & 0,14 & 0,80 & 0,23 & 0,58 & 0,73 & 0,02 & 0,02 & 0,17 & 0,01 & 0,07 \\
\hline MALEZYA & 0,09 & 0,08 & 0,84 & 0,19 & 0,71 & 0,85 & 0,02 & 0,01 & 0,12 & 0,01 & 0,10 \\
\hline BAE & 0,13 & 0,11 & 0,78 & 0,11 & 0,61 & 0,78 & 0,06 & 0,02 & 0,22 & 0,02 & 0,13 \\
\hline KUVEYT & 0,12 & 0,08 & 0,85 & 0,09 & 0,66 & 0,78 & 0,02 & 0,04 & 0,28 & 0,01 & 0,12 \\
\hline TÜRKİYE & 0,08 & 0,00 & 0,66 & 0,31 & 0,63 & 0,96 & 0,05 & 0,01 & 0,25 & 0,01 & 0,10 \\
\hline BAHREYN & 0,13 & 0,06 & 0,75 & 0,17 & 0,50 & 0,70 & 0,09 & 0,06 & 0,22 & 0,00 & 0,03 \\
\hline
\end{tabular}

Tablo 28: 2019 Y1lı Genel Karar Matrisi

\begin{tabular}{|c|c|c|c|c|c|c|c|c|c|c|c|}
\hline ÜLKELER (2019) & $\mathbf{1}$ & $\mathbf{2}$ & $\mathbf{3}$ & $\mathbf{4}$ & $\mathbf{5}$ & $\mathbf{6}$ & $\mathbf{7}$ & $\mathbf{8}$ & $\mathbf{9}$ & $\mathbf{1 0}$ & $\mathbf{1 1}$ \\
\hline SUUDİ ARABİSTAN & 0,16 & 0,14 & 0,79 & 0,25 & 0,62 & 0,79 & 0,02 & 0,02 & 0,11 & 0,02 & 0,12 \\
\hline MALEZYA & 0,10 & 0,09 & 0,84 & 0,19 & 0,73 & 0,87 & 0,02 & 0,01 & 0,10 & 0,01 & 0,09 \\
\hline BAE & 0,15 & 0,12 & 0,76 & 0,11 & 0,60 & 0,79 & 0,06 & 0,02 & 0,21 & 0,02 & 0,12 \\
\hline KUVEYT & 0,12 & 0,08 & 0,85 & 0,09 & 0,63 & 0,73 & 0,01 & 0,04 & 0,32 & 0,01 & 0,11 \\
\hline TÜRKİY & 0,08 & 0,01 & 0,78 & 0,36 & 0,58 & 0,74 & 0,05 & 0,01 & 0,35 & 0,01 & 0,09 \\
\hline BAHREYN & 0,12 & 0,07 & 0,58 & 0,20 & 0,48 & 2,72 & 0,11 & 0,05 & 0,18 & 0,01 & 0,05 \\
\hline
\end{tabular}

Tablo 29: Ülkelerim Toplam Aktif Büyüklükleri (2012-2019)

\begin{tabular}{|c|c|c|c|c|c|c|c|c|}
\hline Toplam Aktif Büyüklükleri (Milyar Dolar) & $\mathbf{2 0 1 2}$ & $\mathbf{2 0 1 3}$ & $\mathbf{2 0 1 4}$ & $\mathbf{2 0 1 5}$ & $\mathbf{2 0 1 6}$ & $\mathbf{2 0 1 7}$ & $\mathbf{2 0 1 8}$ & $\mathbf{2 0 1 9}$ \\
\hline SUUDİ ARABİSTAN & 217 & 264 & $\mathbf{2 9 1}$ & 316 & 371 & 376 & 390 & 443 \\
\hline MALEZYA & 194 & 170 & 137 & 123 & 166 & 201 & 214 & 233 \\
\hline BAE & 95 & 113 & 136 & 159 & 163 & 180 & 194 & 180 \\
\hline KUVEYT & 73 & 83 & 89 & 84 & 87 & 95 & 100 & 115 \\
\hline TÜRKIYE & 35 & 45 & 45 & 42 & 37 & 42 & 39 & 48 \\
\hline BAHREYN & 43 & 60 & 14 & 15 & 75 & 30 & 35 & 86 \\
\hline
\end{tabular}

